\title{
Assessment of the water and sediments quality around the coastal submarine sewage outfall in Guarujá, São Paulo, Brazil
}

A valiação da qualidade da água e dos sedimentos no entorno do emissário submarino costeiro do Guarujá, São Paulo, Brasil

Evaluación de la calidad del agua y los sedimentos alrededor del emisario submarino costero de aguas residuales en Guarujá, São Paulo, Brasil

Received: 09/08/2021 | Reviewed: 09/14/2021 | Accept: 09/18/2021| Published: 09/19/2021

Vinicius Roveri
ORCID: https://orcid.org/0000-0001-7812-8467
Universidade Metropolitana de Santos, Brasil
Universidade Fernando Pessoa, Portugal
Centro Interdisciplinar de Investigação Marinha e Ambiental, Portugal
E-mail: viniciusroveri @ bol.com.br
Luciana Lopes Guimarães
ORCID: https://orcid.org/0000-0002-7230-9571
Universidade Santa Cecília, Brasil
E-mail: lucianafarm@ unisanta.br
Walter Barrella
ORCID: https://orcid.org/0000-0001-9038-7840
Universidade Paulista, Brasil
E-mail: walterbarrella@ gmail.com
Alberto Teodorico Correia
ORCID: https://orcid.org/0000-0002-2831-025X
Universidade Fernando Pessoa, Portugal
Universidade do Porto, Portugal
Onalual
Centro Interdisciplinar de Investigação Marinha e Ambiental, Portugal
E-mail: atcorreia.ciimar@gmail.com

\begin{abstract}
The discharge of domestic sewage is one of the most common types of marine pollution, namely through submarine outfalls. In this study, water and sediments of the coastal submarine sewage outfall in Guarujá, São Paulo, Brazil were assessed during the high (January) and low (April) tourist seasons in 2018. The Canadian Council of Ministers of the Environmental Water Quality Index (CCMEWQI) showed a "marginal" water quality, in both seasons, where dissolved oxygen, biochemical oxygen demand, oil and greases, ammonia, surfactants, aluminium, lead, copper, nickel, Escherichia coli and Enterococci showed potential ecological risks. However, no mutagenic potential was detected in the complex mixture (Ames Salmonella/microsome test: MI<2), and no protozoa and Salmonella bacteria were found. In the sediment, a total of 25 benthic taxa were inventoried, suggesting that the macrofauna is not under contamination stress. Cadmium, lead, copper, chromium, nickel and zinc were below the Threshold Effect Level, and the Geoaccumulation Index was $<0$. Furthermore, the absence of acute toxicity to the test organism Kalliapseudes schubartii (EC50: 96h) and the Shannon-Wiener diversity index (H': 2.5 to 3.5 bits/ind) suggests healthy or unpolluted environments. However, the deviation of some environmental indicators suggests the need of continuous monitoring based on field measurements.
\end{abstract}

Keywords: Subtropical zone; Waste treatment; Ocean dumping; Marine ecology; Pollution effects.

\section{Resumo}

A descarga de esgotos domésticos é um dos tipos mais comuns de poluição marinha, nomeadamente através de emissários submarinos. Neste estudo, a água e os sedimentos do emissário submarino costeiro de Guarujá, São Paulo, Brasil foram avaliados em 2018, durante a alta temporada (janeiro) e a baixa temporada turística (abril). A qualidade da água foi classificada como 'regular' quando aplicamos o CCMEWQI em ambas as estações, onde oxigênio dissolvido, demanda bioquímica de oxigênio, óleos e graxas, amônia, surfactantes, alumínio, chumbo, cobre, níquel, Escherichia coli e Enterococci apresentaram potenciais riscos ecológicos. No entanto, nenhum potencial mutagênico foi detectado na mistura complexa (Ames Salmonella/ teste de microssoma: MI <2), e nenhum protozoário ou bactéria Salmonella foram encontrados. No sedimento, um total de 25 táxons bentônicos foram inventariados, sugerindo que a macrofauna não está sob estresse de contaminação. Cádmio, chumbo, cobre, cromo, níquel e zinco ficaram abaixo do Nível de Efeito Limiar e o Índice de Geoacumulação foi <0. Além disso, a ausência de toxicidade aguda para o organismo de teste Kalliapseudes schubartii (EC50: 96h) e o índice de diversidade de Shannon-Wiener (H': 2,5 a 3,5 
bits/ind) sugere ambientes saudáveis ou não poluídos. No entanto, o desvio de alguns indicadores ambientais sugere a necessidade de monitoramento contínuo com base em medições de campo.

Palavras-chave: Zona subtropical; Tratamento de esgoto; Despejo no oceano; Ecologia marinha; Efeitos da poluição.

\section{Resumen}

La descarga de aguas residuales domésticas es uno de los tipos más comunes de contaminación marina, a saber, a través de emisarios submarinos. En este estudio, el agua y los sedimentos del emisario submarino costero de aguas residuales en Guarujá, São Paulo, Brasil, fueron relevados durante las temporadas alta (enero) y baja (abril) turística en 2018. El Consejo Canadiense de Ministros del Índice de Calidad Ambiental del Agua (CCMEWQI) mostró una calidad de agua "marginal", en ambas temporadas, donde el oxígeno disuelto, la demanda bioquímica de oxígeno, aceites y grasas, amoníaco, surfactantes, aluminio, plomo, cobre, níquel, Escherichia coliy, y Enterococci presentaron riesgos ecológicos potenciales. Sin embargo, no se detectó potencial mutagénico en la mezcla compleja (prueba de Ames Salmonella/microsoma: MI <2), y no se encontraron protozoos ni bacterias Salmonella. En el sedimento, se inventariaron un total de 25 taxones bentónicos, lo que indica que la macrofauna no está bajo estrés de contaminación. El cadmio, el plomo, el cobre, el cromo, el níquel y el zinc estaban por debajo del nivel de efecto umbral y el índice de geoacumulación era $<0$. Además, la ausencia de toxicidad aguda para el organismo de prueba Kalliapseudes schubartii (EC50: 96h) y el índice de diversidad de Shannon-Wiener (H': 2.5 a 3.5 bits/ ind) sugiere ambientes saludables o no contaminados. Sin embargo, la desviación de algunos indicadores ambientales sugiere la necesidad de un monitoreo continúo basado en mediciones de campo.

Palabras clave: Zona subtropical; Tratamiento de desechos; Vertimiento en el océano; Ecología marina; Efectos de la contaminación.

\section{Introduction}

Worldwide population density increase in coastal areas has been highly responsible for the alteration of marine ecosystems (Pelling and Blackburn, 2013; Libhaber, 2016), for instance namely due to untreated municipal sewage discharges (Cesar et al., 2007; Soto-Jiménez et al., 2011; De La Ossa Carretero et al., 2012). Sewage disposal, especially in the marine environment, is a cause of great public concern (Baptistelli and Marcellino, 2016; Ortiz et al., 2016) and has been reported in several studies around the world, such Castellon Coast/Spain (De La Ossa Carretero et al., 2008; 2012), Gulf of Thermaikos/Greece (Christophoridis et al., 2009), and Darwin Harbor/Australia (Padovan et al., 2012). Although the average sewage composition is $99.9 \%$ water and only $0.1 \%$ contaminants (Libhaber, 2016), this former fraction represents a complex physical, chemical, and biological mixture, which may lead to the depletion of oxygen levels (Bleninger et al., 2016), eutrophication ( $\mathrm{N}$ and $\mathrm{P}$ enrichment) (Heisler et al., 2008; Howarth, 2008), introduction of pathogenic organisms (Olalemi et al., 2016), and heavy metal contamination (Christophoridis et al., 2009). This complex mixture can cause severe changes in the environmental quality of waters (Christophoridis et al., 2009; Tabrez et al., 2011) and sediments (Gonzalez et al., 1999; Santi and Tavares, 2009) in areas adjacent to oceanic sewage disposals (Cesar et al., 2007; Soto-Jiménez et al., 2011; De La Ossa Carretero et al., 2012).

In Brazil (the fifth largest country in the world), where approximately 50 million people live in coastal municipalities (along 8,500 km of coastline) (Ibge, 2018), the sewage contamination is particularly evident. Here, the 17 coastal states are served by 20 wastewater treatment plants (WWTP) with preliminary levels of treatment (Lamparelli and Ortiz, 2007; De Souza Abessa et al., 2012), including the WWTP of Guarujá city, in São Paulo State (Baptistelli and Marcellino, 2016). Each WWTP performs only a mechanical treatment (railing and screening for the removal of solids), followed by chlorination. The final destination of the preconditioned sewage is a submarine outfall, that disposes the sewage daily into the marine environment (South Atlantic Ocean) (Cesar et al., 2007; Lamparelli and Ortiz, 2007; De Souza Abessa et al., 2012). These systems are chosen mainly due to their lower maintenance and operation costs (10 to 20 times lower than a secondary system) (Roberts, 2016) and minimum space requirements (Libhaber, 2016), which makes them an ideal alternative for developing countries such as Brazil (Bleninger et al., 2016).

Submarine outfall plans are projected with a more than 20 years timeline, which means that the cumulative effects in the water and sediment matrices are not fully evident in the initial years of the operation (Lamparelli and Ortiz, 2007). Several 
studies on the discharge of emissaries have been carried out on the coast of São Paulo, but the main focus of the scientific community has been the submarine outfall of Santos (municipality located to the east of Guarujá), which is the oldest in the region, built in the 1970s (e.g., Moser et al., 2004; Cesar et al., 2007; De Souza Abessa et al., 2012). However, there are few studies dedicated to the Guarujá submarine outfall, with the exception of the annual monitoring program (water and sediment) carried out since 2010 by the Environmental Agency of the State of São Paulo (Cetesb) (Cetesb, 2017). The Guarujá submarine outfall has been operating for the last 20 years (Baptistelli and Marcellino, 2016) but, as far as it is known, no data exists about the impact of its discharges on the aquatic biota (benthic macrofauna) and/or on the presence of bacteria (Salmonella), and protozoa (Cryptosporidium and Giardia). Moreover, environmental monitoring in the adjacent areas of the oceanic route of this submarine outfall is extremely important in order to propose any improvement to this obsolete system. Recently, our group evaluated the water quality of the urban runoff flowing into the public beaches and recreational waters of Guarujá, São Paulo State, Brazil using a similar approach highlighting the need of better water management practices, improvement of basic sanitation and population awareness (Roveri et al., 2020a; 2020b; 2021).

The present study intended to evaluate the water (physical, chemical, and microbiological parameters, including mutagenicity tests) and sediment quality (heavy metals, ecotoxicological tests and benthic macroinvertebrates) in the adjacent areas of the submarine outfall of Guarujá, in São Paulo, Brazil.

\section{Material and Methods}

\subsection{Study area}

This study was carried out in sub basin-13, island of Santo Amaro, Guarujá, microregion of Santos, São Paulo State, Brazil. It is an area with 316,000 inhabitants (Ibge, 2018) and $143 \mathrm{~km}^{2}$ and $64 \mathrm{~km}$ of extension, of which $107 \mathrm{~km}{ }^{2}$ is made up of environmental protection areas and $36 \mathrm{~km}^{2}$ of urbanised areas (Ribeiro and Oliveira, 2015; Roveri et al., 2020c).

On the island of Santo Amaro, there are two distinct seasonal periods: one rainy season from November to March, and a dry season that occurs from April to October (Cetesb, 2017; Roveri et al., 2020c). The annual precipitation of the region ranges between 2.500 and $3.000 \mathrm{~mm}$, and the annual mean temperature is $22^{\circ} \mathrm{C}$ (Cetesb, 2017; Roveri et al., 2020c). The municipality's economy is mainly driven by three activities; two of which are non-seasonal, occurring in the western portion of the island and characterised by trade in the district of Vicente de Carvalho and by port-related activities in the Santos port (the largest in Latin America). A third activity, which takes place in the eastern and southern portions of the island, is tourism, providing economic benefits to locals in 26 beaches and almost doubling the number of inhabitants, especially during the high summer season (between December and February) (Ribeiro and Oliveira, 2015; Cetesb, 2017; Roveri et al., 2020c).

The municipal sewage is treated through a combined system. The largest parcel, covering six tourist beaches and four neighbourhoods, is served by a WWTP using a preliminary treatment (Cetesb, 2017). This WWTP consists of a set of crates, sandbox and sieve, which aims to remove only the solid and floating material from the sewage, followed by a chlorination step, to eliminate pathogenic microorganisms (Baptistelli and Marcellino, 2016; Ortiz et al., 2016). The final destination of the preconditioned sewage is a submarine outfall, that is $4,500 \mathrm{~m}$ long and $14 \mathrm{~m}$ in depth, disposing $1.45 \mathrm{~m}^{3} / \mathrm{s}$ of sewage daily into the marine environment (Enseada beach). The other parcel, covering the neighbourhood of the district of Vicente de Carvalho, is served by a WWTP characterised by a secondary level of treatment, which empties into the Acaraú River, located at the other end of the island. Together, both systems are sized for a population of approximately 450,000 inhabitants (Cetesb, 2017).

\subsection{Sampling procedures}

Guarujá city has an environmental agency monitoring program in the vicinity of the oceanic layout of the submarine outfall, which samples, twice a year, water and sediment matrices (Cetesb, 2017). In the present study, two field campaigns 
were carried out: one on the January 2018 during the high tourist season (summer/rainy season), and another on the April 2018 in the low tourist season (dry/fall season). We adopted two of the already existent environmental agency sampling points: P1: $24^{\circ} 01^{\prime} 39,7^{\prime \prime}$; $46^{\circ}$ 13' 27, 5"W and P2: 24 01' 34, 3"S; 46 13' 21, 3"W. Both points: P1 (Southwest) and P2 (Northeast) are located about 100 meters from the discharge site (Figure1). During the sampling procedures, no rainfall was recorded in the last 48 hours prior to both campaigns.

Figure 1: Map showing Guarujá municipality location, in the state of São Paulo, Brazil. The two sampling points (P1: red circle and P2: blue circle) are located around the coastal submarine sewage outfall in Guarujá (Enseada beach, South Atlantic Ocean).

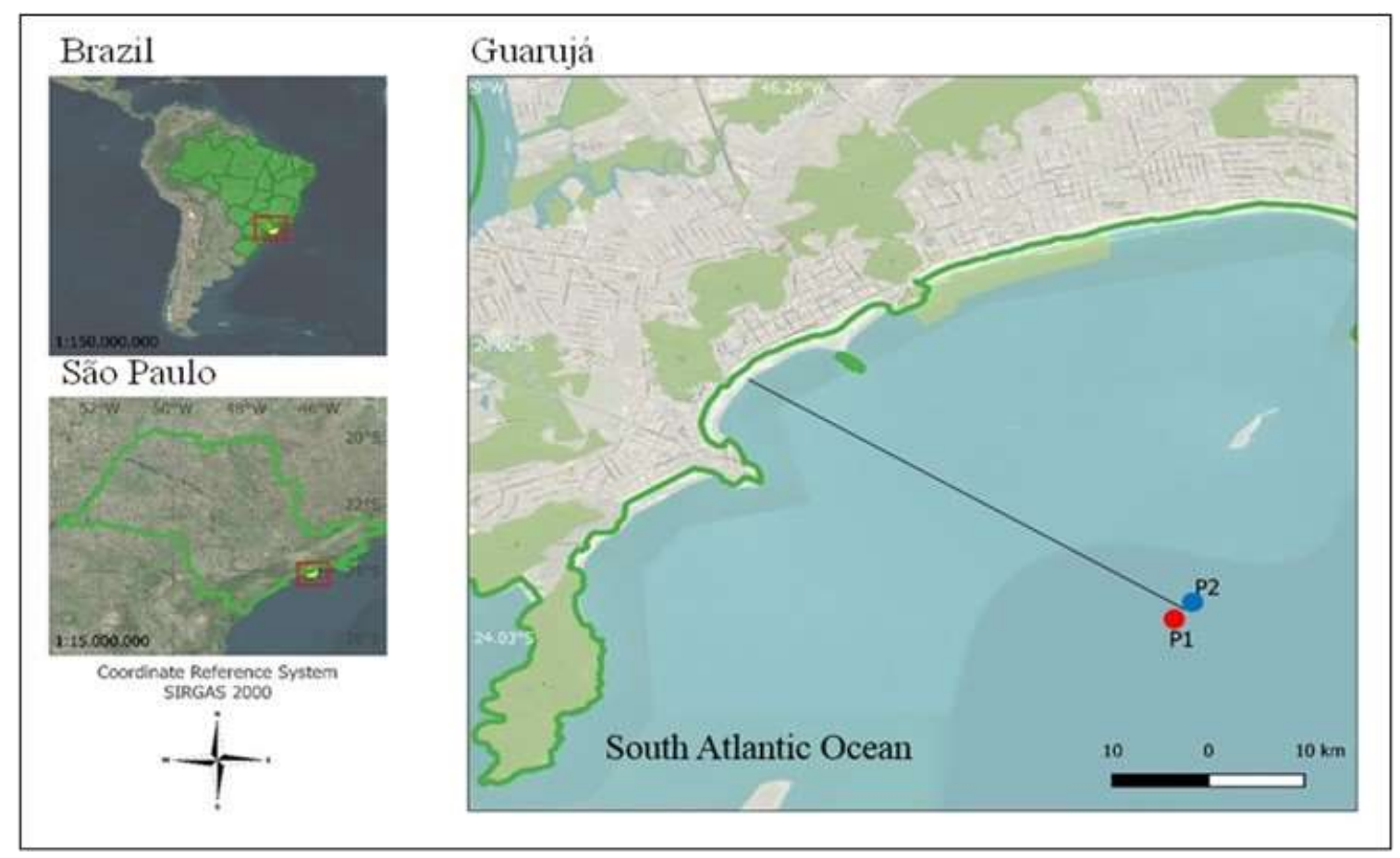

Source: Authors.

Prior to sampling campaigns, measurements were made in loco for the following variables: air and water temperatures, water density, salinity, conductivity (Ec), absolute conductivity, dissolved oxygen (DO), and pH. These measurements were performed with the aid of a multiparameter probe (HANNA HI 98184, calibrated with standard solution prior to start of each campaign). The colour of the water (Hanna photometer - HI 83200/01) and its turbidity (Hanna - HI 98703/01 turbidimeter) were also obtained in the field. Thereafter, samples from different environmental matrices (e.g., water and sediment) were obtained following the national guidelines for the collection and preservation of samples (Cetesb, 2011). The water was collected using a Van Dorn bottle at two different depths: surface (1 meter) and bottom (10 meters). The sediment, obtained at a depth of 14 meters, was collected with a Ponar dredge with an area of $0.037 \mathrm{~m}^{2}$. Samples were labelled according to the sampling points (P1 and P2), collection seasons [high (H) and low (L) tourist seasons], and water depths [surface (A), bottom (B), or sediment (C)]. Samples were kept in refrigerated conditions $\left(\leq 6^{\circ} \mathrm{C}\right)$ and the respective collection flasks, previously sterilized, were sent for laboratory to further analysis.

Ammonia $\left(\mathrm{NH}_{3}\right)$, nitrites $\left(\mathrm{NO}_{2}{ }^{-}\right)$and nitrates $\left(\mathrm{NO}_{3}{ }^{-}\right)$, phosphate $\left(\mathrm{PO}_{4}{ }^{3}-\right)$, and anionic surfactants (MBAS) in the water samples were analyzed in the Research Laboratory of Natural Products of the Santa Cecília University - Unisanta/Santos/São Paulo.

In the laboratory Analytical Control Analyzes Techniques, in Osasco/SP (accreditation of Inmetro/ABNT ISO/ 
IEC17025), the following water analyzes were performed: i) physicochemical analyses: sedimented solids (SS); biochemical oxygen demand (BOD), and oils and greases (OG); ii) heavy metals (also in sediments): aluminium (Al), cadmium (Cd), lead $(\mathrm{Pb})$, copper $(\mathrm{Cu})$, chromium $(\mathrm{Cr})$, nickel $(\mathrm{Ni})$, and zinc $(\mathrm{Zn})$; and iii) microbiological analyses: Escherichia Coli (E. coli), Enterococci, Salmonella, Cryptosporidium, and Giardia.

The Ames Salmonella/microsome mutagenicity assay [(Ames test: lineages TA98 and TA100, with and without metabolism system (S9)] was sent to the NSF Bioassays laboratory, Viamão/Rio Grande do Sul (accreditation of Inmetro/ABNT ISO/ IEC17025). In the present study, the Ames test was performed through a composite sample (only during low season/April) added to a 2-liter flask: point P1 (P1-LA: $500 \mathrm{~mL}$ and P1-LB: $500 \mathrm{~mL}$ ) and P2 (P2-LA: 500 mL and P2-LB: $500 \mathrm{~mL})$.

The acute toxicity test (integral sediment - CE50; 96h) with the tanaidacean Kalliapseudes schubartii was performed by the NSF Bioassays laboratory, Viamão/Rio Grande do Sul.

The identification and quantification of benthic macroinvertebrates and the granulometric analysis (fractionation of the sediment in sand, silt and clay), was performed by the Econsult Laboratory, in Guarujá, São Paulo (accreditation of Inmetro/ABNT ISO/ IEC17025).

All analyzes were carried out in triplicate, and all variables (in water and sediment matrices) and analytical methods adopted in this study are fully detailed in Table 1.

The obtained results from water (physicochemical and microbiological) were assessed according to the current national legislation [(guidelines of the Conama Resolution - National Environmental Council No. 357/2005, marine waters/class 1 (Brazil, 2005)]. Due to the lack of quality standards for sediments in Brazilian legislation, the results of heavy metals were compared to the quality criteria established by the Canadian Environmental Assessment Agency (CCME, 2001a), which establishes two distinct limits: one for the threshold effect (TEL - Threshold Effect Level) and another, above which severe effects are expected (PEL - Probable Effect Level). 
Table 1: Analytical methods (with definition of the quantification limit and standard reference) applied to water (physical, chemical - including heavy metals, microbiological and mutagenicity test) and sediment variables (heavy metals, ecotoxicological test, benthic macroinvertebrates including granulometric analysis) of samples collected around the coastal submarine sewage outfall in Guarujá, São Paulo, Brazil.

\begin{tabular}{|c|c|c|c|c|}
\hline \multicolumn{2}{|r|}{ Variables } & \multirow{2}{*}{\begin{tabular}{|c|} 
Method \\
Imhoff Cone
\end{tabular}} & \multirow{2}{*}{$\begin{array}{c}\begin{array}{c}\text { Limit of } \\
\text { Quantification } \\
\text { (L.Q) }\end{array} \\
0.10 \mathrm{mg} / \mathrm{L} \\
\end{array}$} & \multirow{2}{*}{$\begin{array}{c}\text { Standard reference } \\
\text { 2540F (APHA, 2012) }\end{array}$} \\
\hline \multirow{8}{*}{ 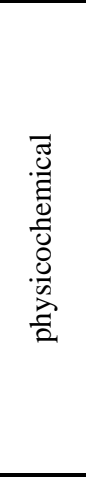 } & sedimented solids (SS) & & & \\
\hline & biochemical oxygen demand (BOD) & Electrometric & $2.00 \mathrm{mg} / \mathrm{L}$ & 5210B (APHA, 2012) \\
\hline & oils and greases (OG) & Liquid-liquid gravimetric & $5.00 \mathrm{mg} / \mathrm{L}$ & 5520D (APHA, 2012) \\
\hline & ammonia $\left(\mathrm{NH}_{3}\right)$ & \multirow{5}{*}{ Spectrophotometry } & $0.001 \mathrm{mg} / \mathrm{L}$ & 4500D (APHA, 1999) \\
\hline & nitrite $\left(\mathrm{NO}_{2-}\right)$ & & $0.001 \mathrm{mg} / \mathrm{L}$ & \multirow[b]{2}{*}{ 4500B (APHA, 2005) } \\
\hline & nitrate $\left(\mathrm{NO}_{3}-\right)$ & & $0.001 \mathrm{mg} / \mathrm{L}$ & \\
\hline & phosphate $\left(\mathrm{PO}_{4}{ }^{3}-\right)$ & & $0.001 \mathrm{mg} / \mathrm{L}$ & 4500E (APHA, 2012) \\
\hline & anionic surfactants (MBAS) & & $0.01 \mathrm{mg} / \mathrm{L}$ & 3500B (APHA, 2005) \\
\hline \multirow{7}{*}{ 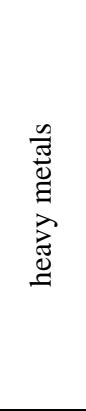 } & aluminium $(\mathrm{Al})$ & \multirow{7}{*}{$\begin{array}{l}\text { Atomic absorption } \\
\text { spectrophotometry }\end{array}$} & $0.025 \mathrm{mg} / \mathrm{L}$ & \multirow{7}{*}{ 3120B (APHA, 2017) } \\
\hline & cadmium $(\mathrm{Cd})$ & & $0.001 \mathrm{mg} / \mathrm{L}$ & \\
\hline & lead $(\mathrm{Pb})$ & & $0.005 \mathrm{mg} / \mathrm{L}$ & \\
\hline & copper $(\mathrm{Cu})$ & & $0.001 \mathrm{mg} / \mathrm{L}$ & \\
\hline & chrome $(\mathrm{Cr})$ & & $0.005 \mathrm{mg} / \mathrm{L}$ & \\
\hline & nickel (Ni) & & $0.005 \mathrm{mg} / \mathrm{L}$ & \\
\hline & zinc $(\mathrm{Zn})$ & & $0.05 \mathrm{mg} / \mathrm{L}$ & \\
\hline \multirow{5}{*}{ 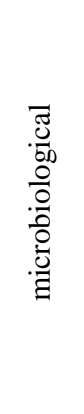 } & Escherichia Coli (E. coli) & Filter membrane technique & $1 \mathrm{CFU} / \mathrm{mL}$ & 9222B (APHA, 2012) \\
\hline & Enterococci & Filter membrane technique & $1 \mathrm{CFU} / \mathrm{mL}$ & 9230C (APHA, 2012) \\
\hline & Salmonella & Presence or absence technique & - & 9260B (APHA,2012) \\
\hline & Cryptosporidium & \multirow[t]{2}{*}{$\begin{array}{l}\text { Immunomagnetic separation and } \\
\text { immunofluorescence microscopy }\end{array}$} & 1 Oocyst/L & \multirow[t]{2}{*}{1623.1 (EPA, 2012) } \\
\hline & Giardia & & 1 cyst $/ \mathrm{L}$ & \\
\hline 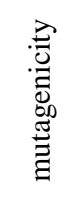 & mutagenicity assay & $\begin{array}{c}\text { Ames test, lineages TA98 and } \\
\text { TA100 } \\
\text { Method } 471 \text { - Adopted: 21st July } \\
1997\end{array}$ & - & OECD (1997) \\
\hline 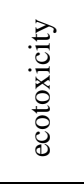 & acute toxicity & $\begin{array}{c}\text { integral sediment }\left(\mathrm{CE}_{50 ; 96 \mathrm{~h}}\right)- \\
\text { Tanaidacea Kalliapseudes schubartii }\end{array}$ & - & Zamboni and Costa (2002) \\
\hline : & benthic macroinvertebrates: & Identification and quantification & $1 \mathrm{org} . / \mathrm{m}^{2}$ & 10500 (APHA, 2012) \\
\hline
\end{tabular}




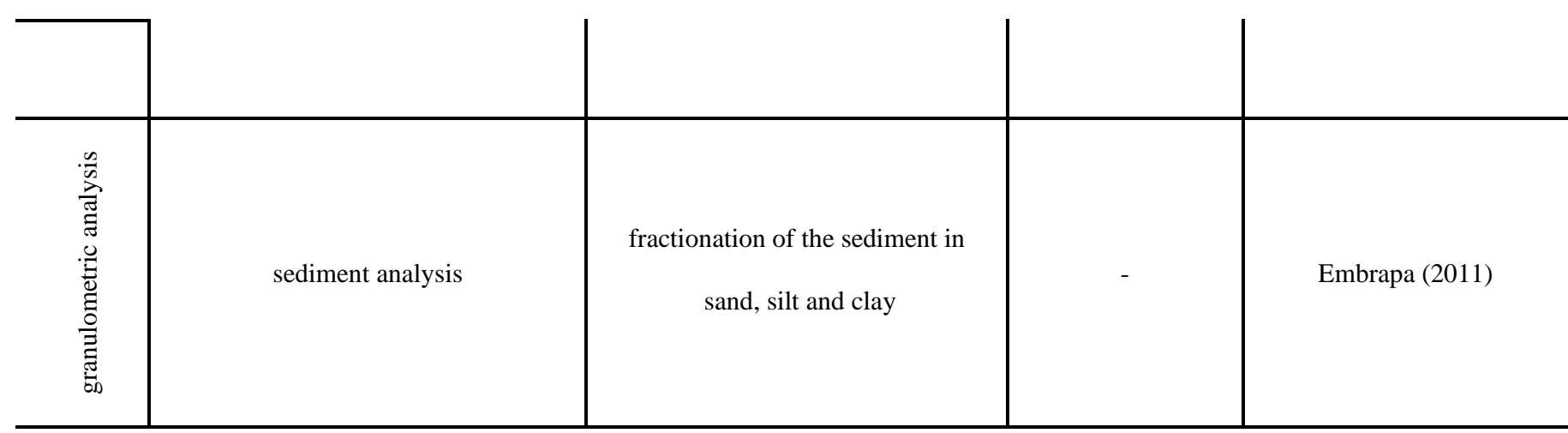

Source: Authors.

\subsection{Quality indexes}

\subsubsection{Canadian Council of Ministers of the Environment Water Quality Index (CCMEWQI)}

In addition to the individual analyses of each abiotic variable, the following quality indexes were also adopted. The CCMEWQI was developed by the Canadian Council of Ministers of the Environment: Water Quality Guidelines (CCME, 2001b), with the purpose of assessing the compliance of water quality goals (Conama No. 357/2005, class 1). The calculation of index scores using the CCMEWQI method can be obtained by using the following formula (Eq.1):

$$
W Q I=100-\frac{\sqrt{F 1^{2}+F 2^{2}+F 3^{2}}}{1.732}(E q .1)
$$

Where: The range (F1) evaluates the number of variables that show non-conformity; the frequency (F2) evaluates the amount of non-conformities as a whole and does not differentiate within variables; and the amplitude (F3), that refers to non compliance with the current legislation (Conama No. 357/2005, class 1). This index allows the classification of the water as: excellent (95-100), good (80-94), fair (65-79), marginal (45-64), or poor (0-44) (CCME, 2001b).

\subsubsection{Mutagenicity Index (MI)}

The mutagenicity index (MI) was calculated for each concentration tested according to the following formula (Eq.2):

$$
\mathrm{MI}=\frac{\text { number of revertants per plate (test compound) }}{\text { number of revertants per plate (negative control) }}(E q .2)
$$

The sample is considered mutagenic when the MI is $\geq 2$ in at least one of the concentrations tested (Mortelmans and Zeiger, 2000).

\subsubsection{Geoaccumulation Index (GeoI)}

The GeoI was determined as a quantitative measure of pollution in sediments caused by heavy metals (Moreira and Boaventura, 2003), and can be obtained through the following equation (Eq.3):

$$
\text { Geol }=\log 2[\mathrm{Cn}(1.5 \mathrm{Bn})-1](E q .3)
$$

Where: $\mathrm{Cn}$ is the concentration of metal $\mathrm{n}$ in the sediment and $\mathrm{Bn}$ the metallic contents indicated by the TEL (Thresholds Effects Levels) (CCME, 2001a). The 1.5 factor in the equation is used to compensate for possible variations of 
background data caused by lithological differences, which allows the degree of contamination of different areas to be compared. According to this index, sediments are classified as: basal level $(\mathrm{GeoI}<0)$, uncontaminated $(0 \leq \mathrm{GeoI} \leq 1)$, uncontaminated to moderately contaminated $(1 \leq \mathrm{GeoI} \leq 2)$, moderately contaminated $(2 \leq$ GeoI $\leq 3)$, moderately to heavily contaminated $(3 \leq \mathrm{GeoI} \leq 4)$, heavily contaminated $(4 \leq \mathrm{GeoI} \leq 5)$, or highly contaminated $(\mathrm{GeoI}>5)$.

\subsubsection{Shannon's diversity index $\left(\mathrm{H}^{\prime}\right)$}

Shannon's Index $\left(\mathrm{H}^{\prime}\right)$, applied to benthic macroinvertebrates, measures the degree of uncertainty in predicting which species a randomly chosen individual will belong to from a sample with $\mathrm{S}$ species and $\mathrm{N}$ individuals. Diversity tends to be higher as the index value increases. The $\mathrm{H}^{\prime}$ is calculated through the following equation (Eq.4):

$$
H^{s}=\sum_{i=1}^{s} p i \ln p i(E q \cdot 4)
$$

Where: pi is the frequency of each species, for i ranging from 1 to $\mathrm{S}$ (Wealth) (Magurran, 1988).

\subsubsection{Statistical analysis}

The Mann-Whitney U test, a nonparametric statistic, was used to compare the physicochemical and microbiological variables of water between seasons [high $(\mathrm{H})$ and low $(\mathrm{L})$ ] and depths [surface (A) and bottom (B)]. The correlation between ( $\mathrm{H}$ x L) and (A x B) was evaluated using Spearman's correlation coefficient (Hollander and Wolfe, 2013). Only physicochemical and microbiological variables that were quantified in all campaigns and points were selected for correlation. Perceptual maps were developed, via Principal Component Analysis (PCA), in order to visualize the correlations between variables. For sediment, PCA was also applied to order the results of physicochemical variables of the bottom portion of the waters (specifically organic indicators BOD and DO), sediments (granulometry and heavy metal content), and the most representative benthic taxa in the quantitative analysis, as well as the total density of this community (Mingoti, 2005). The software Past (Paleontological Statistics), version 2.17c (Hammer et al., 2001), was used to perform these analyses. In the mutagenicity test, the dose-response curves were evaluated by the SALANAL (Salmonella typhimurium Assay Analysis statistical method developed by Environmental Monitoring Systems Laboratory, EPA - Software version 1,0 - ILS, NC, 275 USA), which includes analysis of variance and linear regression. A sample is considered positive when it presents a statistically significant difference to the negative control through ANOVA $(\mathrm{p} \leq 0.05)$; significantly positive dose-response effect $(\mathrm{p} \leq 0.05)$. The results of the acute toxicity test (integral sediment - CE50; 96h), using the tanaidacean Kalliapseudes schubartii, were compared to the control with Student's t-test for independent samples to determine the differences with the respective controls. All statistics adopted the level of significance $(\alpha)$ of 0.05 (Zamboni and Costa, 2002).

\section{Results}

\subsection{Water}

Although the field work occurred in two distinct climatic periods, onsite measurements showed that the air temperature was very similar in both seasons $\left(27^{\circ} \mathrm{C}\right.$ and $26^{\circ} \mathrm{C}$ for summer and autumn, respectively). Water density was lower at the surface in comparison to the bottom, with inverse conditions when compared to water temperature. At all points, the salinity levels were within the expected range for the sampled water body (salinity $\geq 30 \%$ ). The results of both campaigns showed Ec between 51.04 and $52.37 \mathrm{mS} / \mathrm{cm}$ and absolute conductivity (without interference of temperature) between 53.85 and $55.67 \mathrm{mS} / \mathrm{cm}$ (Table 2). 
The maximum concentration for turbidity was 4.30 NTU recorded in point P2-LB, and the pH values obtained in both campaigns (7.30 to 7.49) revealed the water to be slightly alkaline (Table 2). The colour showed maximum values of 34.00 $\mathrm{mgPt} / \mathrm{L}$ (point P2-HB), and the SS were $<0.10 \mathrm{mg} / \mathrm{L}$ throughout the study (Table 2). The DO values were low in all campaigns, with sampling points ranging from 2.29 to $4.64 \mathrm{mg} / \mathrm{L}$. Conversely, BOD values (with the exception of point P1-LA) were high in both campaigns (159.00 to $456.00 \mathrm{mg} / \mathrm{L}$ ) (Table 2). Organic substances such as OG (5.20 to $5.80 \mathrm{mg} / \mathrm{L}$ ) were detected only in surface samples (points P1-HA, P2-HA, P1-LA, and P2-LA) (Table 2). The results demonstrate a predominance of $\mathrm{NH}_{3}$ $(0.18$ to $0.44 \mathrm{mg} / \mathrm{L})$ in relation to $\mathrm{NOx}\left(\mathrm{NO}_{2}{ }^{-}+\mathrm{NO}_{3}{ }^{-}\right)$in both seasons (Table 2). $\mathrm{PO}_{4}{ }^{3}-(0.06$ to $0.31 \mathrm{mg} / \mathrm{L})$ and $\mathrm{MBAS}(1.32$ to $2.71 \mathrm{mg} / \mathrm{L}$ ) were detected in both campaigns and in all sampling points (Table 2). Bacteria, such as E. coli (187 to 887 $\mathrm{CFU} / \mathrm{mL}$ ) and Enterococci (112 to $450 \mathrm{CFU} / \mathrm{mL}$ ), were also detected in both campaigns and at all sampling points (Table 2). Other pathogenic organisms, such as Salmonella, were absent in all analyzes. The protozoa were below the limit of quantification (L.Q) (Cryptosporidium: L.Q < 1 Oocyst/L and Giardia: L.Q < 1 cyst/L) (Table 2). Al (1.02 to $1.77 \mathrm{mg} / \mathrm{L}), \mathrm{Pb}$ ( 0.01 to $0.02 \mathrm{mg} / \mathrm{L}), \mathrm{Cu}(0.038$ to $0.088 \mathrm{mg} / \mathrm{L})$, and Ni metals $(0.036$ to $0.038 \mathrm{mg} / \mathrm{L})$ were detected only in water samples from the low season collected from the bottom (points P1-LB and P2-LB) (Table 2). The CCMEWQI results showed a "marginal" water quality, in both seasons: 64.01 (P1) and 63.06 (P2) (Table 2).

Table 2: Results of the physical, chemical (total of 24 variables), and microbiological (total of 8 variables) analyses of water samples collected around the coastal submarine sewage outfall in Guarujá, São Paulo, Brazil. Two field campaigns were carried out: one during the high tourist season (summer/rainy season: points: P1-HA e P2-HA) and another in the low tourist season (dry/fall season: points P1-LA and P2-LA). The water was collected at two different depths: surface (1 meter) and bottom (10 meters). The results were compared to the standard of the CONAMA (Brazilian National Environmental Council, No. 357/2005 - Class 1). The final column of the table shows the CCMEWQI index results (Canadian Council of Ministers of the Environment Water Quality Index). Notes: $(-----)=$ without of the CONAMA standard reference. $(*)=$ Does not meet the CONAMA reference standard. $(<\mathrm{L} . \mathrm{Q})=$ Limit of Quantification. $(\mathrm{N} . \mathrm{D})=$ Not detected. $(\mathrm{P} / \mathrm{N})=$ Positive/Negative $(\mathrm{A} / \mathrm{P})=$ Absence/Presence.

\begin{tabular}{|c|c|c|c|c|c|c|c|c|c|c|c|}
\hline \multicolumn{2}{|c|}{ Variables } & \multirow[t]{2}{*}{ Unit } & \multicolumn{4}{|c|}{ High season } & \multicolumn{4}{|c|}{ Low season } & \multirow{2}{*}{$\begin{array}{c}\text { Standard } \\
\text { Reference } \\
\text { (Brazil, } \\
\text { 2005) }\end{array}$} \\
\hline & & & P1-HA & P1-HB & P2-HA & $\mathrm{P} 2-\mathrm{HB}$ & P1-LA & P1-LB & P2-LA & P2-LB & \\
\hline \multirow{14}{*}{ 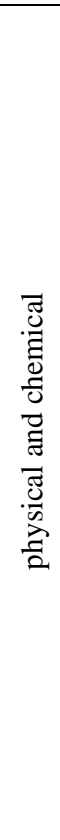 } & water temperature & ${ }^{\circ} \mathrm{C}$ & 27.89 & 27.41 & 27.92 & 27.33 & 28.48 & 28.06 & 28.30 & 28.07 & ----- \\
\hline & density & $\sigma \mathrm{t}$ & 21.32 & 21.41 & 21.39 & 21.55 & 20.93 & 21.87 & 21.82 & 21.92 & ------ \\
\hline & salinity & $\%$ & 33.52 & 33.43 & 33.63 & 33.59 & 34.26 & 34.33 & 34.37 & 34.40 & ------ \\
\hline & conductivity (Ec) & $\mathrm{mS} / \mathrm{cm}$ & 51.17 & 51.04 & 51.32 & 51.28 & 52.21 & 52.26 & 52.36 & 52.37 & ----- \\
\hline & absolute conductivity & $\mathrm{mS} / \mathrm{cmA}$ & 53.98 & 53.85 & 54.17 & 54.12 & 55.66 & 55.40 & 55.54 & 55.67 & ----- \\
\hline & dissolved oxygen (DO) & $\mathrm{mg} / \mathrm{L}$ & $4.52 *$ & $4.49 *$ & $4.64 *$ & $4.58 *$ & $4.31 *$ & $2.29 *$ & $4.33^{*}$ & $2.22 *$ & $\geq 6.00$ \\
\hline & turbidity & NTU & 1.00 & 1.30 & 1.80 & 3.40 & 1.00 & 1.40 & 2.40 & 4.30 & ----- \\
\hline & $\mathrm{pH}$ & $\mathrm{pH}$ & 7.45 & 7.33 & 7.49 & 7.34 & 7.49 & 7.42 & 7.46 & 7.30 & $\begin{array}{c}6.50 \text { to } \\
8.50\end{array}$ \\
\hline & colour & $\mathrm{mgPt} / \mathrm{L}$ & 16.00 & 26.00 & 28.00 & 34.00 & 21.00 & 29.00 & 30.00 & 33.00 & ------ \\
\hline & sediment solids (SS) & $\mathrm{mg} / \mathrm{L}$ & $<0.10$ & $<0.10$ & $<0.10$ & $<0.10$ & $<0.10$ & $<0.10$ & $<0.10$ & $<0.10$ & ------ \\
\hline & $\begin{array}{c}\text { biochemical oxygen } \\
\text { demand (BOD) }\end{array}$ & $\mathrm{mg} / \mathrm{L}$ & 159.00 & 239.00 & 182.00 & 238.00 & 2.90 & 321.00 & 456.00 & 402.00 & ----- \\
\hline & oil and grease $(\mathrm{OG})$ & $\mathrm{mg} / \mathrm{L}$ & $5.80^{*}$ & $<\mathrm{L} . \mathrm{Q}$ & $5.70 *$ & $<\mathrm{L} . \mathrm{Q}$ & $5.20^{*}$ & $<\mathrm{L} . \mathrm{Q}$ & $5.20 *$ & $<\mathrm{L} . \mathrm{Q}$ & $\begin{array}{c}\text { virtually } \\
\text { absent }\end{array}$ \\
\hline & ammonia $\left(\mathrm{NH}_{3}\right)$ & $\mathrm{mg} / \mathrm{L}$ & 0.18 & 0.27 & 0.19 & 0.20 & 0.28 & $0.41 *$ & $0.44 *$ & $0.80 *$ & 0.40 \\
\hline & nitrites $\left(\mathrm{NO}_{2}^{-}\right)$ & $\mathrm{mg} / \mathrm{L}$ & 0.002 & 0.001 & 0.004 & 0.004 & 0.003 & 0.004 & 0.004 & 0.007 & 0.07 \\
\hline
\end{tabular}


Research, Society and Development, v. 10, n. 12, e257101220389, 2021

(CC BY 4.0) | ISSN 2525-3409 | DOI: http://dx.doi.org/10.33448/rsd-v10i12.20389

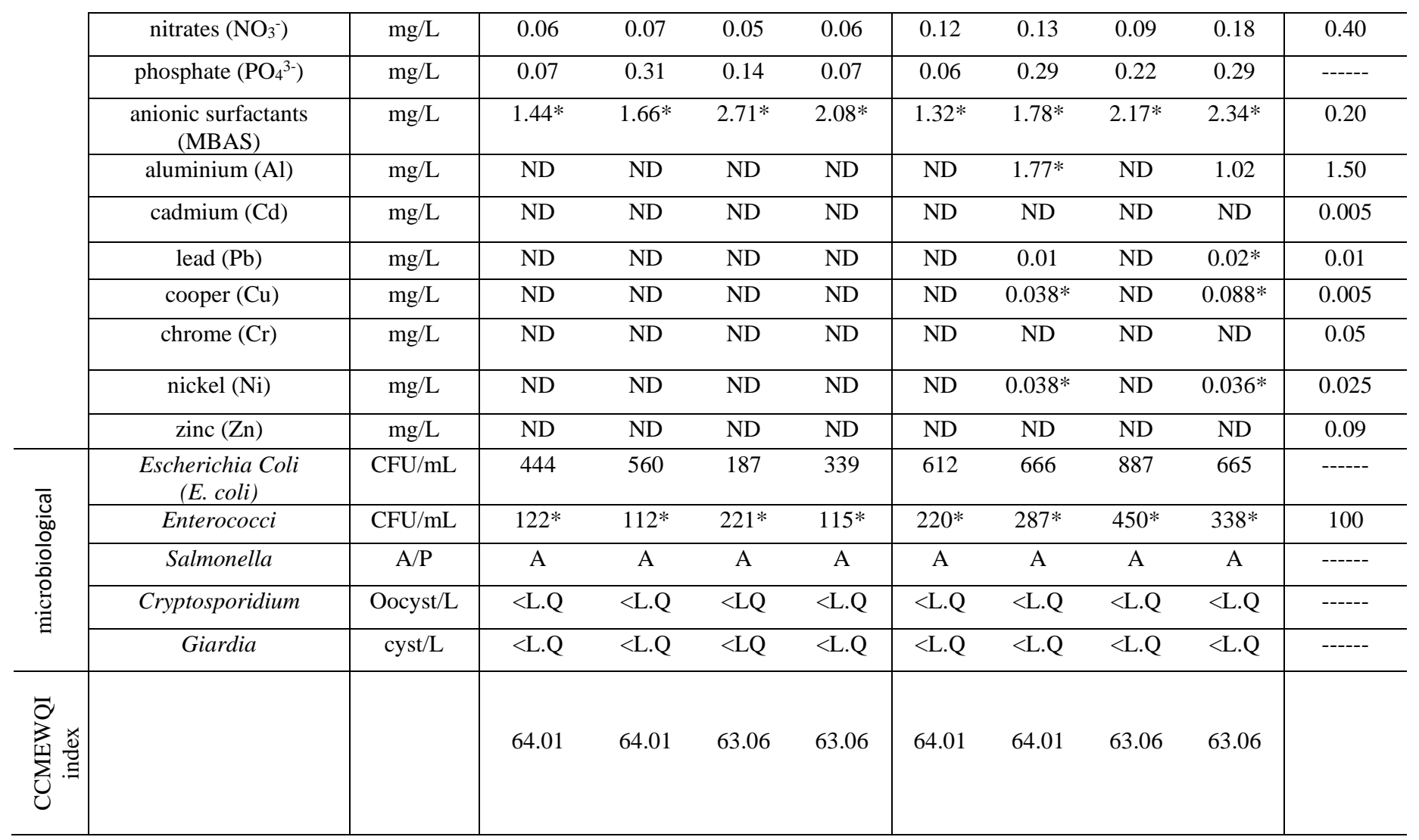

Source: Authors.

Figure 2 shows the perceptual map (PCA) considering the variables that were quantified in all campaigns and collection points (water and air temperature, density, salinity, Ec, absolute conductivity, DO, turbidity, pH, colour, BOD, $\mathrm{NH}_{3}$, $\mathrm{NO}_{2-}, \mathrm{NO}_{3^{-}}, \mathrm{PO}_{4}{ }^{3}-, \mathrm{MBAS}$, E. coli and Enterococci) (Table 2), between seasons: high (H) and low (L) (Figure 2a) and collection points surface: (A) and bottom (B) (Figure 2b). This set of variables was able to discriminate the two seasons very well, and with the exception of DO, all variables showed the highest values during the low season (L). However, the set of variables was unable to discriminate between surface (A) and bottom (B). 
Figure 2: Perceptual map via Principal Component Analysis (PCA), applied to water variables: physical, chemical, and microbiological (including air temperature) and sediment (heavy metals, benthic macro invertebrates, and granulometric analysis) of samples collected in the mix zone of the coastal submarine sewage outfall in Guarujá, São Paulo, Brazil. Three distinct scenarios were considered: (A): Principal Component Analysis (PCA) of comparison between the means of the 17 variables (water) and 1 of air (temperature) to verify in which period: high season $[(\mathrm{H})$ (identification: black triangle)] or low season [(L) (identification: black square)] there was worse environmental conditions. At these two stations, the following combined analyses were carried out between collection points: high season $(\mathrm{H})$ : [(point P1 - HA) + (point P1 - HB) + (point P2 - HA) + (point P2 - HB)] and in low season (L): [(points P1- LA) + (points P1 - LB) + (points P2 - LA) + (points P2 - LB)]. (B): Principal Component Analysis (PCA) of comparison between the means of the 17 variables (water) and 1 of air (temperature) to verify at what depth: surface [(A) (identification: black star)] or bottom [(B) (identification: black diamond)] there was worse environmental conditions. At these two depths, the following combined analyses were carried out between collection points: surface (A): [(point P1- HA) + (point P2 - HA) + (point P1 - LA) + (point P2 - LA)] and in bottom (B): $[($ points P1 - HB) + (points P2 - HB) + (points P1 - LB) + (points P2 - LB)]. (C): Principal Component Analysis (PCA) of abiotic water variables (DO and BOD - obtained in the bottom portion), sediment (seven heavy metals: $\mathrm{Al}, \mathrm{Zn}, \mathrm{Cr}, \mathrm{Pb}, \mathrm{Cu}, \mathrm{Ni}$, $\mathrm{Cd}$ ), grain size fraction (silt, clay and sand) together with benthic macrofauna collected during the high (H) and low season (L). On the positive axis, the abiotic variables ( $\mathrm{BOD}$ and $\mathrm{Al}, \mathrm{Zn}, \mathrm{Cr}, \mathrm{Pb}, \mathrm{Cu}, \mathrm{Ni}, \mathrm{Cd}$ ) were collected together with the grain size fractions (silt and clay), polychaetes (Paraonidae) and bivalves. These variables presented higher contributions in the low season. On the negative axis, the abiotic variables (DO), the sand fraction, the polychaetes (Lumbrineridae and Goniadidae), and the amphipods were collected. This group of variables presented greater contributions in the high season. Points of reference in the sediment: in high season $(\mathrm{H})$ [(point P1-HC: identification: red triangle) and (P2 - HC: identification: blue triangle)] and in the low season (L) [(point P1-LC: identification: red square) and (point P2 - LC: identification: blue square)].
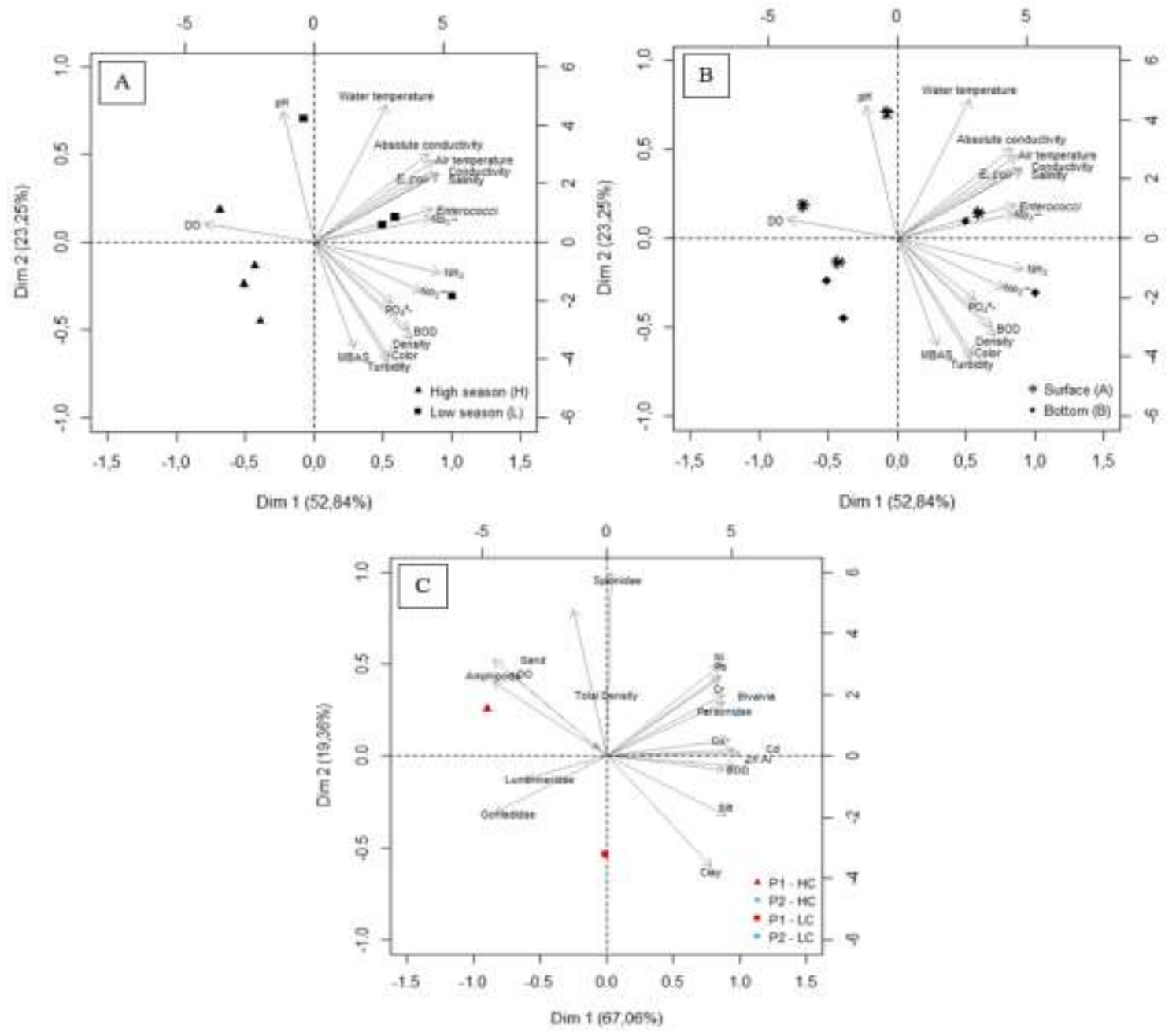

Source: Authors. 
Regarding the mutagenicity assay, the mean number of revertant colonies on the negative control plates for all strains was within the spontaneous mutation frequency range of the laboratory history (period: July, to February 2018) (Tables 3a, 3b, $3 \mathrm{c}, 3 \mathrm{~d}, 3 \mathrm{e}$ and $3 \mathrm{f})$. The results also demonstrate that the number of revertant colonies on the positive control plaques confirms the reversal property and specificity of each test line and the efficiency of the metabolic activation system. The statistical analysis of the results presented in Tables $3 \mathrm{a}$ and 3b (TA98) and Tables 3c and 3d (TA100) demonstrate that the sample was not able to induce reverse mutations His+ (ANOVA P Variance > 0.05 and P dose-response > 0.05) for both strains, both in the presence and absence of the metabolic system (S9). In addition, for these strains, at any concentration of the tested sample, the frequency of revertant colonies His+ was always less than twice the frequency of revertant colonies in the negative control, that is, the values of the mutagenicity index (MI) were always $<2$ (Tables $3 \mathrm{a}, 3 \mathrm{~b}, 3 \mathrm{c}$ and $3 \mathrm{~d}$ ).

Table 3: Results of the Ames Salmonella/microsome test (Ames test) performed through a composite sample of water collected around the coastal submarine sewage outfall in Guarujá, São Paulo, Brazil. The field campaign was conducted only during the low tourist season (dry season / fall season). The composite sample (total of 2 litters) was sterilised by filtration membrane $(0.22 \mu \mathrm{m})$ and tested for induction of reverse mutation for locus His in two lineages of Salmonella typhimurium: [TA98 (Tables 3a and 3b)] and [TA100 (Tables 3c and 3d)]. The Ames tests were performed by modified the pre-incubation method, in the absence [(-S9) (Tables 3a and 3c)] and presence [(+S9) (Tables 3b and 3d)] of the metabolic activation mixture (S9). The assays were performed in increasing amounts of sample (triplicates). The doses tested were 100, 200, 500, 1000, 1500, and $2000 \mu \mathrm{L} /$ plate. All experiments included a negative control (100 $\mu \mathrm{L} \mathrm{H} 2 \mathrm{O} /$ plate). The positive control was applied according to that indicated for each lineage: [TA98 (-S9): 4 nitroquinoline 1-oxide (0,5 $\mu \mathrm{g} / \mathrm{plate})$ (Table 3a)]; [TA98 (+S9): 2 Aminofluorene (10 $\mu \mathrm{g} / \mathrm{plate})$ (Table 3b)]; [TA100 (-S9): Sodium azide (1 $\mu \mathrm{g} / \mathrm{plate})$ (Table 3c)]; [TA100 (+S9): 2 Aminofluorene (10 $\mu \mathrm{g} /$ plate) (Tables 3d)]. The results (average \pm standard deviations) were expressed in Revertant His $+/$ plate, and the Mutagenicity Index was calculated (MI) (Tables 3a to 3d). Tables 3e and 3f shown the historical Ames test [(TA98 and TA100 with (-S) and without (+S9)] performed by the NSF Bioassays laboratory, Viamão/Rio Grande do Sul/Brazil (test period: July 2003 to February 2018). The historical laboratory results are expressed in average \pm standard deviation; $\mathrm{n}=$ sample size and minimum and maximum values.

(a)

\begin{tabular}{|c|c|c|c|c|c|c|}
\hline \multicolumn{7}{|c|}{ TA98: Without metabolization (-S9) } \\
\hline \multirow{2}{*}{ Substance } & \multirow{2}{*}{$\begin{array}{l}\text { Concentration } \\
(\mu \mathrm{L} / \text { plate })\end{array}$} & \multicolumn{3}{|c|}{ Revertant His+/plate (- S9) } & \multirow{2}{*}{$\begin{array}{c}\text { Average } \pm \\
\text { standard deviation }\end{array}$} & \multirow[b]{2}{*}{$\begin{array}{l}\text { Mutagenicity Index } \\
\text { (MI) }\end{array}$} \\
\hline & & Replica 1 & Replica 2 & Replica 3 & & \\
\hline $\begin{array}{c}\text { Negative control } \\
(100 \mu \mathrm{L} \mathrm{H} 2 \mathrm{O} / \text { plate })\end{array}$ & 0 & 34 & 46 & 39 & $39.67 \pm 6.03$ & \\
\hline Salmonella typhimurium & 100 & 42 & 36 & 50 & $42.67 \pm 7.02$ & 1.08 \\
\hline Salmonella typhimurium & 200 & 43 & 40 & 42 & $41.67 \pm 1.53$ & 1.05 \\
\hline Salmonella typhimurium & 500 & 32 & 46 & 46 & $41.33 \pm 8.08$ & 1.04 \\
\hline Salmonella typhimurium & 1000 & 36 & 36 & 45 & $39.00 \pm 5.20$ & 0.98 \\
\hline Salmonella typhimurium & 1500 & 38 & 41 & 41 & $40.00 \pm 1.73$ & 1.01 \\
\hline Salmonella typhimurium & 2000 & 32 & 36 & 41 & $36.33 \pm 4.51$ & 0.92 \\
\hline $\begin{array}{c}\text { Positive control } \\
\text { (4 nitroquinoline } 1 \text {-oxide) }\end{array}$ & $0,5 \mu \mathrm{g}$ & 634 & 628 & & $631.00 \pm 4.24$ & 15.91 \\
\hline
\end{tabular}


(b)

\begin{tabular}{|c|c|c|c|c|c|c|}
\hline \multicolumn{7}{|c|}{ TA98: With metabolization $(+S 9)$} \\
\hline \multirow{2}{*}{ Substance } & \multirow{2}{*}{$\begin{array}{l}\text { Concentration } \\
(\mu \mathrm{L} / \text { plate })\end{array}$} & \multicolumn{3}{|c|}{ Revertant His+/plate (+ S9) } & \multirow{2}{*}{$\begin{array}{c}\text { Average } \pm \\
\text { standard deviation }\end{array}$} & \multirow[b]{2}{*}{$\begin{array}{l}\text { Mutagenicity Index } \\
\text { (MI) }\end{array}$} \\
\hline & & Replica 1 & Replica 2 & Replica 3 & & \\
\hline $\begin{array}{c}\text { Negative control } \\
\text { (100 } \mu \mathrm{L} \text { H2O / plate })\end{array}$ & 0 & 42 & 46 & 49 & $45.67 \pm 3.51$ & \\
\hline Salmonella typhimurium & 100 & 47 & 48 & 49 & $48.00 \pm 1.00$ & 1.05 \\
\hline Salmonella typhimurium & 200 & 44 & 42 & 47 & $44.33 \pm 2.52$ & 0.97 \\
\hline Salmonella typhimurium & 500 & 42 & 49 & 51 & $47.33 \pm 4.73$ & 1.04 \\
\hline Salmonella typhimurium & 1000 & 44 & 39 & 34 & $39.00 \pm 5.00$ & 0.85 \\
\hline Salmonella typhimurium & 1500 & 41 & 44 & 39 & $41.33 \pm 2.52$ & 0.91 \\
\hline Salmonella typhimurium & 2000 & 47 & 47 & 35 & $43.00 \pm 6.93$ & 0.94 \\
\hline $\begin{array}{l}\text { Positive control } \\
\text { (2 Aminofluorene) }\end{array}$ & $10 \mu \mathrm{g}$ & 1065 & 728 & & $896.50 \pm 238.29$ & 19.63 \\
\hline
\end{tabular}

(c)

\begin{tabular}{|c|c|c|c|c|c|c|}
\hline \multicolumn{7}{|c|}{ TA100: Without metabolization (-S9) } \\
\hline \multirow{2}{*}{ Substance } & \multirow{2}{*}{$\begin{array}{l}\text { Concentration } \\
(\mu \mathrm{L} / \text { plate })\end{array}$} & \multicolumn{3}{|c|}{ Revertant His+/plate (- S9) } & \multirow{2}{*}{$\begin{array}{c}\text { Average } \pm \\
\text { standard deviation }\end{array}$} & \multirow[b]{2}{*}{$\begin{array}{l}\text { Mutagenicity Index } \\
\text { (MI) }\end{array}$} \\
\hline & & Replica 1 & Replica 2 & Replica 3 & & \\
\hline $\begin{array}{c}\text { Negative control } \\
(100 \mu \mathrm{L} \mathrm{H} 2 \mathrm{O} / \text { plate })\end{array}$ & 0 & 163 & 121 & 138 & $140.67 \pm 21.13$ & \\
\hline Salmonella typhimurium & 100 & 144 & 137 & 141 & $140.67 \pm 3.51$ & 1.00 \\
\hline Salmonella typhimurium & 200 & 140 & 131 & 138 & $136.33 \pm 4.73$ & 0.97 \\
\hline Salmonella typhimurium & 500 & 133 & 145 & 163 & $147.00 \pm 15.10$ & 1.05 \\
\hline Salmonella typhimurium & 1000 & 140 & 141 & 109 & $130.00 \pm 18.19$ & 0.92 \\
\hline Salmonella typhimurium & 1500 & 113 & 129 & 109 & $117.00 \pm 10.58$ & 0.83 \\
\hline Salmonella typhimurium & 2000 & 98 & 129 & 112 & $113.00 \pm 15.52$ & 0.80 \\
\hline $\begin{array}{l}\text { Positive control } \\
\text { (Sodium azide) }\end{array}$ & $1 \mu \mathrm{g}$ & 1064 & 1176 & & $1120.00 \pm 79.20$ & 7.96 \\
\hline
\end{tabular}

(d)

\begin{tabular}{|c|c|c|c|c|c|c|}
\hline \multirow{2}{*}{ Substance } & \multirow{2}{*}{$\begin{array}{c}\text { Concentration } \\
(\mu \mathrm{L} / \text { plate })\end{array}$} & \multicolumn{3}{|c|}{ Revertant His+/plate (+ S9) } & \multirow{2}{*}{$\begin{array}{l}\text { Average } \pm \\
\text { standard deviation }\end{array}$} & \multirow[b]{2}{*}{$\begin{array}{c}\text { Mutagenicity Index } \\
\text { (MI) }\end{array}$} \\
\hline & & Replica 1 & Replica 2 & Replica 3 & & \\
\hline $\begin{array}{c}\text { Negative control } \\
(100 \mu \mathrm{L} \text { H2O / plate })\end{array}$ & 0 & 97 & 107 & 121 & $108.33 \pm 12.06$ & \\
\hline Salmonella typhimurium & 100 & 96 & 89 & 109 & $98.00 \pm 10.15$ & 0.90 \\
\hline Salmonella typhimurium & 200 & 109 & 108 & 106 & $107.67 \pm 1.53$ & 0.99 \\
\hline Salmonella typhimurium & 500 & 105 & 101 & 114 & $106.67 \pm 6.66$ & 0.98 \\
\hline Salmonella typhimurium & 1000 & 97 & 98 & 93 & $96.00 \pm 2.65$ & 0.89 \\
\hline
\end{tabular}




\begin{tabular}{c|c|c|c|c|c|c}
\hline Salmonella typhimurium & 1500 & 108 & 100 & 90 & $99.33 \pm 9.02$ & 0.92 \\
\hline Salmonella typhimurium & 2000 & 100 & 90 & 109 & $99.67 \pm 9.50$ & 0.92 \\
\hline $\begin{array}{c}\text { Positive control } \\
\text { (2 Aminofluorene) }\end{array}$ & $10 \mu \mathrm{g}$ & 644 & 860 & & $752.00 \pm 152.74$ & 6.94 \\
\hline
\end{tabular}

Source: Authors.

\subsection{Sediment}

The concentration of heavy metals in sediments was $\mathrm{Al}>\mathrm{Zn}>\mathrm{Cr}>\mathrm{Pb}>\mathrm{Cu}>\mathrm{Ni}>\mathrm{Cd}$, at both sampling points, with a tendency to be higher during the low season, when a higher proportion of fine grains was also recorded (silt and clay). The Geoaccumulation Index was classified at a basal level (Geol<0) (Table 4). An absence of acute toxicity to the test organism Kalliapseudes schubartii (Crustacea: Tanaidacea) was observed, which had a survival rate $\geq 80 \%$ (method limit) that was statistically equal to the control.

The list of taxa sampled at discharge of the Guarujá submarine outfall, and their respective quantitative results, density, and relative abundance, are shown in Table 5. A total of 25 benthic macroinvertebrates taxa were recorded being distributed among the groups Polychaeta (11), Mollusca (6), Crustacea (5), Hemichordata (1), Nematoda (1), and Nemertea (1) for both sampling points and field campaigns. In the Guarujá submarine outfall, part of the collected taxa was recorded in the two evaluated periods, with six unique taxa identified in the high season and ten taxa verified only in the low season (Table 5). A density of 1215 org. $/ \mathrm{m}^{2}$ (point P1-HC) and 810 org. $/ \mathrm{m}^{2}$ (point P2-HC) were obtained for the high season, and 756 org. $/ \mathrm{m}^{2}$ (point P1-LC) and 1053 org. $/ \mathrm{m}^{2}$ (point P2-LC), in the low season (Table 5). Polychaeta were dominant in most of the samples obtained in both collections, with a density of up to $594 \mathrm{org} . / \mathrm{m}^{2}$ at $\mathrm{P} 1-\mathrm{HC}$, during the high season. However, P2-HC is an exception for this sampling, because crustaceans were more numerous (351 org. $/ \mathrm{m}^{2}$ ), although the maximum result for this group was also obtained in P1-HC, with org. $/ \mathrm{m}^{2}$. Molluscs were also observed, reaching a density of 351 org. $/ \mathrm{m}^{2}$ (point P2LC) in the low season, while other groups were less abundant in the samples (Table 5). Among crustaceans, the order Amphipoda was more representative, with 378 org. $/ \mathrm{m}^{2}$ (point P1-HC) during the high season. Bivalves accounted for the highest densities of molluscs, with $270 \mathrm{org} . / \mathrm{m}^{2}$ in low season (point P2-LC).

The PCA showed that axes 1 and 2 accounted for $86.42 \%$ of the data variability, $67.06 \%$ for the first axis and $19.36 \%$ for the second axis (Figure 2c). The metals present in the sediments were placed on the positive axis 1 along with the silt and clay particle size fractions, the BOD, the depositivore polychaetes of the family Paraonidae, and also the bivalves. To this set, the samples obtained during the low season were added, in which these elements occurred in relatively higher amounts. In the negative portion of this axis, the sand fraction, DO, the most carnivorous polychaetes of the families Lumbrineridae and Goniadidae and the amphipods were correlated, which tended to present higher contributions during the high season. Data from the benthic community were synthesized through the diversity $\left(H^{\prime}\right)$ index. The low season recorded a greater diversity, with 3.26 bits/ind (point P1-LC) and 3.33 bits/ind (point P2-LC), while in the high season, H' remained between 2.84 bits/ind (point P1- 372 HC) and 2.95 bits/ind (point P2-HC) (Table 5). 
Table -4: Results of heavy metals ( $\mathrm{Al}, \mathrm{Cd}, \mathrm{Pb}, \mathrm{Cu}, \mathrm{Cr}, \mathrm{Ni}$ and $\mathrm{Zn}$ ) and granulometric (sand, silt and clay) analysis of samples collected around the coastal submarine sewage outfall in Guarujá, São Paulo, Brazil. Two field campaigns were carried out: one during the high tourist season (summer/rainy season: points P1-LC and P2-LC) and another in the low tourist season (dry/fall season: points P1-LC and P2-LC). The sediment was collected at 14 meters deep. Results of the heavy metals analysis was compared to the CCME (Canadian Council of Ministers of the Environment) standard of reference, which establishes two distinct limits: one for the threshold effect (TEL - Threshold Effect Level) and another, above which severe effects are expected (PEL - Probable Effect Level), and, in the last column last, results of the Geoaccumulation Index (Geol) analysis calculated for the heavy metals. Note: (-----) without CCME normative reference. (N.A) Geol not applicable.

\begin{tabular}{|c|c|c|c|c|c|c|c|c|}
\hline \multirow[b]{2}{*}{ Variables } & \multirow[b]{2}{*}{ Unit } & \multicolumn{2}{|c|}{ High season } & \multicolumn{2}{|c|}{ Low season } & \multicolumn{2}{|c|}{$\begin{array}{l}\text { Standard reference } \\
\text { (CCME, 2001a) }\end{array}$} & \multirow{2}{*}{$\begin{array}{l}\text { Geoacumulation } \\
\text { Index } \\
\text { (Geol) }\end{array}$} \\
\hline & & $\begin{array}{c}\text { P1-HC } \\
\text { (sediment) }\end{array}$ & $\begin{array}{l}\text { P2-HC } \\
\text { (sediment) }\end{array}$ & $\begin{array}{c}\text { P1-LC } \\
\text { (sediment) }\end{array}$ & $\begin{array}{c}\text { P2-LC } \\
\text { (sediment) }\end{array}$ & $\begin{array}{c}\text { Threshold } \\
\text { Effect } \\
\text { Level } \\
\text { (TEL) }\end{array}$ & $\begin{array}{c}\text { Probable } \\
\text { Effect } \\
\text { Level } \\
\text { (PEL) }\end{array}$ & \\
\hline aluminium (Al) & $\mathrm{mg} / \mathrm{Kg}$ & 13600 & 15455 & 15555 & 17899 & ------ & ------ & $<0$ (basal level) \\
\hline cadmium $(\mathrm{Cd})$ & $\mathrm{mg} / \mathrm{Kg}$ & 0.30 & 0.50 & 0.50 & 0.60 & 0.70 & 4.20 & $<0$ (basal level) \\
\hline lead $(\mathrm{Pb})$ & $\mathrm{mg} / \mathrm{Kg}$ & 15.70 & 19.00 & 16.10 & 21.30 & 30.20 & 112.00 & $<0$ (basal level) \\
\hline cooper $(\mathrm{Cu})$ & $\mathrm{mg} / \mathrm{Kg}$ & 11.10 & 13.30 & 12.30 & 14.10 & 18.70 & 108.00 & $<0$ (basal level) \\
\hline chrome $(\mathrm{Cr})$ & $\mathrm{mg} / \mathrm{Kg}$ & 23.10 & 23.90 & 23.30 & 36.30 & 52.30 & 160.00 & $<0$ (basal level) \\
\hline nickel (Ni) & $\mathrm{mg} / \mathrm{Kg}$ & 7.20 & 10.60 & 7.10 & 14.10 & 15.90 & 42.80 & $<0$ (basal level) \\
\hline zinc $(\mathrm{Zn})$ & $\mathrm{mg} / \mathrm{Kg}$ & 58.00 & 66.00 & 76.00 & 94.00 & 124.00 & 271.00 & $<0$ (basal level) \\
\hline Sand & $\%$ & 67 & 56 & 48 & 48 & ------ & ------ & N.A \\
\hline Silt & $\%$ & 25 & 31 & 31 & 32 & ------ & ------ & N.A \\
\hline Clay & $\%$ & 7 & 13 & 21 & 19 & ----- & ------ & N.A \\
\hline
\end{tabular}

Source: Authors. 
Table 5: Results of the taxonomic composition, total density (org. $/ \mathrm{m}^{2}$ ), relative abundance, and total richness of the benthic community of samples collected around the coastal submarine sewage outfall in Guarujá, São Paulo, Brazil. Two field campaigns were carried out: one during the high tourist season (summer/rainy season: points P1-HC and P2-HC) and another in the low tourist season (dry/fall season: points P1-LC and P2-LC). The benthic macrofauna were collected at 14 meters deep. In the final column of the table are the results of Shannon's diversity index $\left(H^{\prime}\right)$ (bits/ind).

\begin{tabular}{|c|c|c|c|c|c|c|c|c|}
\hline \multirow[t]{3}{*}{ Taxonomic composition } & \multicolumn{4}{|c|}{ High season } & \multicolumn{4}{|c|}{ Low season } \\
\hline & \multicolumn{2}{|c|}{ P1-HC } & \multicolumn{2}{|c|}{ P2-HC } & \multicolumn{2}{|c|}{ P1-LC } & \multicolumn{2}{|c|}{ P2-LC } \\
\hline & org. $/ \mathrm{m}^{2}$ & $\%$ & org. $/ \mathrm{m}^{2}$ & $\%$ & org. $/ \mathrm{m}^{2}$ & $\%$ & org. $/ \mathrm{m}^{2}$ & $\%$ \\
\hline \multicolumn{9}{|l|}{ Phylum ANNELIDA } \\
\hline \multicolumn{9}{|l|}{ Class Polychaeta } \\
\hline \multicolumn{9}{|l|}{ Subclass Aciculata } \\
\hline \multicolumn{9}{|l|}{ Order Eunicida } \\
\hline Family Lumbrineridae & 243 & 20.0 & 54 & 6.7 & 189 & 25.0 & 108 & 10.3 \\
\hline Family Onuphidae & - & - & - & - & - & - & 27 & 2.6 \\
\hline \multicolumn{9}{|l|}{ Order Phyllodocida } \\
\hline Family Glyceridae & - & - & 27 & 3.3 & - & - & - & - \\
\hline Family Goniadidae & 216 & 17.8 & 108 & 13.3 & 189 & 25.0 & 81 & 7.7 \\
\hline Family Hesionidae & - & - & - & - & - & - & 27 & 2.6 \\
\hline Family Pilargidae & - & - & - & - & 27 & 3.6 & 54 & 5.1 \\
\hline Family Polynoidae & 27 & 2.2 & - & - & - & - & - & - \\
\hline \multicolumn{9}{|l|}{ Subclass Canalipalpata } \\
\hline \multicolumn{9}{|l|}{ Order Sabellida } \\
\hline Family Oweniidae & - & - & - & - & 27 & 3.6 & - & - \\
\hline \multicolumn{9}{|l|}{ Order Spionida } \\
\hline Family Magelonidae & 27 & 2.2 & - & - & - & - & - & - \\
\hline Family Spionidae & 81 & 6.7 & 54 & 6.7 & - & - & 81 & 7.7 \\
\hline \multicolumn{9}{|l|}{ Subclass Scolecida } \\
\hline Family Paraonidae & - & - & - & - & 27 & 3.6 & 189 & 17.9 \\
\hline Subtotal & 594 & 48.9 & 243 & 30.0 & 459 & 60.7 & 567 & $\mathbf{5 3 . 8}$ \\
\hline \multicolumn{9}{|l|}{ Phylum ARTHROPODA } \\
\hline \multicolumn{9}{|l|}{ Subphylum CRUSTACEA } \\
\hline Class Ostracoda & - & - & - & - & - & - & 27 & 2.6 \\
\hline \multicolumn{9}{|l|}{ Class Malacostraca } \\
\hline \multicolumn{9}{|l|}{ Subclass Eumalacostraca } \\
\hline \multicolumn{9}{|l|}{ Superorder Eucarida } \\
\hline \multicolumn{9}{|l|}{ Order Decapoda } \\
\hline \multicolumn{9}{|l|}{ Suborder Pleocyemata } \\
\hline Infraorder Brachyura & - & - & - & - & 27 & 3.6 & 27 & 2.6 \\
\hline Infraorder Caridea & 54 & 4.4 & 27 & 3.3 & 27 & 3.6 & - & - \\
\hline \multicolumn{9}{|l|}{ Superorder Peracarida } \\
\hline Order Amphipoda & 378 & 31.1 & 297 & 36.7 & 54 & 7.1 & - & - \\
\hline Order Cumacea & - & - & 27 & 3.3 & 27 & 3.6 & 27 & 2.6 \\
\hline Subtotal & 432 & 35.6 & 351 & 43.3 & 135 & 17.9 & 81 & 7.7 \\
\hline \multicolumn{9}{|l|}{ Phylum HEMICHORDATA } \\
\hline Class Enteropneusta & 27 & 2.2 & - & - & - & - & - & - \\
\hline
\end{tabular}




\begin{tabular}{|c|c|c|c|c|c|c|c|c|}
\hline Subtotal & 27 & 2.2 & - & - & - & - & - & - \\
\hline \multicolumn{9}{|l|}{ Phylum MOLLUSCA } \\
\hline Class Bivalvia & - & - & - & - & 27 & 3.6 & 270 & 25.6 \\
\hline \multicolumn{9}{|l|}{ Subclass Heterodonta } \\
\hline \multicolumn{9}{|l|}{ Order Veneroida } \\
\hline Family Tellinidae & 81 & 6.7 & 81 & 10.0 & - & - & - & - \\
\hline Family Veneridae & 54 & 4.4 & 54 & 6.7 & 27 & 3.6 & - & - \\
\hline \multicolumn{9}{|l|}{ Subclass Protobranchia } \\
\hline \multicolumn{9}{|l|}{ Order Nuculida } \\
\hline Family Nuculidae & - & - & 54 & 6.7 & - & - & 54 & 5.1 \\
\hline \multicolumn{9}{|l|}{ Class Gastropoda } \\
\hline \multicolumn{9}{|l|}{ Subclass Caenogastropoda } \\
\hline \multicolumn{9}{|l|}{ Order Neogastropoda } \\
\hline Family Columbellidae & - & - & - & - & 54 & 7.1 & 27 & 2.6 \\
\hline Family Olividae & - & - & - & - & 27 & 3.6 & - & - \\
\hline Subtotal & 135 & 11.1 & 189 & 23.3 & 135 & 17.9 & 351 & 33.3 \\
\hline Phylum NEMATODA & - & - & 27 & 3.3 & - & - & - & - \\
\hline Subtotal & - & - & 27 & 3.3 & - & - & - & - \\
\hline Phylum NEMERTEA & 27 & 2.2 & - & - & 27 & 3.6 & 54 & 5.1 \\
\hline Subtotal & 27 & 2.2 & - & - & 27 & 3.6 & 54 & 5.1 \\
\hline Total Density & 1.215 & 100 & 810 & 100 & 756 & 100 & 1.053 & 100 \\
\hline Total Richness & \multicolumn{2}{|c|}{11} & \multicolumn{2}{|c|}{11} & \multicolumn{2}{|c|}{14} & \multicolumn{2}{|c|}{14} \\
\hline Shannon's diversity index $\left(H^{\prime}\right)$ & \multicolumn{2}{|c|}{2.84 bits/ind } & \multicolumn{2}{|c|}{2.95 bits/ind } & \multicolumn{2}{|c|}{3.26 bits/ind } & \multicolumn{2}{|c|}{3.33 bits/ind } \\
\hline
\end{tabular}

Source: Authors.

\section{Discussion}

\subsection{Water}

The main purpose of a Wastewater treatment plant (WWTP) is the removal of floating materials and suspended solids often found in raw wastewater (Libhaber, 2016). The low solid content suspension and turbidity of waters recorded showed that the Guarujá's WWTP is fulfilling its main function. However, organic substances such as OG and MBAS, high BOD load, nutrients (e.g., $\mathrm{NH} 3$ and $\mathrm{PO}_{4}{ }^{3}$ ), and heavy metals (e.g., $\mathrm{Al}, \mathrm{Pb}, \mathrm{Cu}$ and $\mathrm{Ni}$ ), that are usually not removed during this treatment step (Bleninger et al., 2016), were detected at the discharge of this submarine outfall. As a consequence, the physicochemical and microbiological variables indicate environmental/human health potential risks. From the 33 variables analyzed in this study, $\mathrm{OG}, \mathrm{DO}, \mathrm{NH}_{3}, \mathrm{MBAS}, \mathrm{Al}, \mathrm{Pb}, \mathrm{Cu}, \mathrm{Ni}$, and Enterococci were not compliant, at least once, with national legislation. From these 9 variables, a total of 14 and 23 environmental analyzes did not meet the normative standard in the high and low seasons, respectively. As a consequence, the quality of the coastal waters in the vicinity of the Guarujá submarine outfall (in both P1 and P2 stations) was classified as "marginal” (CCME, 2001b).

The Canadian Council of Ministers of the Environmental Water Quality Index (CCMEWQI) index indicates that the water quality is threatened or compromised (CCME, 2001b), since the observed conditions deviate from the normative standards and, thus, from the expected environmental quality (salt water, class 1) (Brazil, 2005). In accordance with Brazilian law, marine waters with classification 1, such as Guarujá, should provide safe conditions for recreation, ensure the protection of aquatic communities, and favour fishing and aquaculture activities (Brazil, 2005). 
In addition to causing aesthetic problems (as well as SS, turbidity, and colour), OG can interfere with the exchange of oxygen between water surface and the atmosphere (lowering the DO), compromising the equilibrium of the ecosystem (Baptistelli and Marcellino, 2016). Low concentrations of DO (e.g., P1-LB and P2-LB points) may be harmful to bottom marine species (e.g., macrobenthos). Changes in amphipod assemblages were related to a hypoxia situation in stations close to sewer emissaries (De La Ossa Carretero et al., 2012). Moreover, hypoxia causes mortality in many invertebrates, and crustaceans are especially sensitive to this lack of oxygen (Gray et al., 2002). The BOD load, mainly at P1LB, P2-LA, and P2-LB points, was higher than $300.00 \mathrm{mg} / \mathrm{L}$, which is a typical concentration for crude domestic sewage and promotes organic enrichment of the marine environment (Cromey et al., 1998). The excess organic matter may cause changes in the number of species, abundance of organisms, and in the biomass of benthic communities (Cromey et al., 1998; Elías et al., 2005).

Nitrogen and phosphorus, as well as DO, are prerequisite requirements for primary production in aquatic ecosystems (Heisler et al., 2008). However, discharges with excess organic material, as observed in Guarujá, can promote a eutrophication process due to nutrient enrichment (Moser et al., 2004; Howarth, 2008). Several studies have shown high concentration of nutrients in the vicinity of worldwide submarine emissaries, such as in Santos and Niterói (Brazil), Mumbai (India), and Boston (USA) (Moser et al., 2004). In more extreme scenarios, eutrophication can trigger proliferation of phytoplankton potentially toxic to both aquatic communities and public health (Heisler et al., 2008; Howarth, 2008).

Eutrophication caused by sewage discharges was responsible for the creation of anoxic zones on the seafloor, causing mortality of benthic organisms in the Black Sea (Gray et al., 2002; Surugiu, 2005). The predominance of $\mathrm{NH}_{3}$ in relation to $\mathrm{NO}_{\mathrm{X}}$ in Guarujá indicates a recent and/or near source of pollution (Baptistelli and Marcellino, 2016; Ortiz et al., 2016). In addition, $\mathrm{NH}_{3}$ (a typical form of untreated domestic sewage), together with the low DO and high BOD, at the discharge of this submarine outfall suggest the occurrence of an active microbiological decomposition process, which is a common process in a mixing water zone (Libhaber, 2016; Ortiz et al., 2016).

In water bodies impacted by sewage, total phosphorus (TP), almost all in the form of $\mathrm{PO}_{4}{ }^{3}$-, is mainly originated by MBAS (up to 50\%), such as linear alkyl sulphonate, that is used worldwide in household cleaning and personal hygiene products (León et al., 2006). MBAS detected in the submarine outfall mixing zone, in conjunction with OG, can impair the exchange of oxygen between water and the atmosphere, causing damage to aquatic biota (Stalmans et al.,1991; Stoll et al., 1997). In addition to remaining on the water surface, detergents also tend to settle on the bottom (Stoll et al., 1997), as observed in the present study. Unfortunately, MBAS have not been a priority in coastal zone monitoring (De Souza Abessa et al., 2012), but there are studies showing their toxicity to aquatic organisms, such as crustaceans (Ole Kusk and Petersen, 1999), and fish (Nunes et al., 2016). Only ineffective sewage treatments (e.g., Guarujá emissaries) can cause high concentrations of MBAS in the surrounding environment, that are capable of causing toxic effects on sensitive marine organisms (e.g., Acartiatonsa-Crustacea) (Ole Kusk and Petersen, 1999). The concentrations of MBAS detected in the Guarujá oceanic layout are above the safety limits (LC50: 50\% Lethal Concentration) for marine organisms at both sampling points and seasons, also observed in the North Sea: cod (Gadus morrhua-LC50: 1mg/L) and sole (Platichthysflesus-LC50: $0.02 \mathrm{mg} / \mathrm{L}$ ) (Stalmans et al.,1991). We suggest the use of aerobic treatment systems with biological degradation and through chemical adsorption/absorption, to properly remove MBAS in a largely effective rate (between 98.8 and $99.9 \%$ ) (León et al., 2006).

The release of sewage with an excess of organic matter is also alarming due to the introduction of pathogenic microorganisms such as bacteria, and protozoa (Ortiz et al., 2016; Roberts, 2016). In this study, the presence of E. coli (present in human faeces in percentages ranging between 96 to 99\%) (Rozen and Belkin, 2001; Selegean et al., 2001), indicated recent faecal contamination, since these bacteria are poorly resistant to the conditions of the marine environment, namely to the levels 
of solar radiation and salinity (Rozen and Belkin, 2001). Enterococci were also detected in this mixture zone. Unlike E. coli, it is characterized by high tolerance to the adverse conditions of the marine environment, which makes it a good indicator of human faecal contamination for longer period monitoring studies (Roslev et al., 2009). It is known that in the vicinity of a submarine outfall, some environmental conditions, such as UV radiation, can cause bacterial decay by up to $90 \%$ in less than one hour (Libhaber, 2016).

This factor is why preliminary systems combined with submarine outfalls are considered an adequate alternative for public health, as they remove sewers from the beach area (Roberts, 2016). However, some studies have demonstrated that the presence of E.coli and Enterococci related to domestic sewage in marine environment can also cause contamination of shell fish species (Colaiuda et al., 2021) namely mussels: Dreissena polymorpha (Selegean et al., 2001), Mytilus edulis (Roslev et al., 2009; Grevskott et al., 2020), and oysters: (Crassostrea gigas) (Olalemi et al., 2016) and (Crassostrea gasar) (Oliveira et al., 2020) with deleterious impacts on fishing activity (Selegean et al., 2001; Roslev et al., 2009; Olalemi et al., 2016).

In regions where there is an oceanic discharge of domestic sewage, studies have already demonstrated the ability of heavy metals to remain in the water column (Wan et al., 2008; Christophoridis et al. 2009), which can be bioaccumulated and biomagnified by aquatic organisms (Soto-Jiménez et al., 2011), and to be adsorbed into the sediment (Gonzalez et al., 1999). Concentrations of $\mathrm{Pb}(0.01$ and $0.02 \mathrm{mg} / \mathrm{L})$ and $\mathrm{Cu}(0.038$ and $0.088 \mathrm{mg} / \mathrm{L})$ in the Guarujá mixing zone (e.g., points P1-LB and P2-LB), exceeded the limits allowed by national legislation (Brazil, 2005) and the maximum concentrations detected near the submarine outfall of Jinzhou Bay/China ( $\mathrm{Pb}: 0.001 \mathrm{mg} / \mathrm{L}$ and $\mathrm{Cu}: 0.002 \mathrm{mg} / \mathrm{L}$ ), with these concentrations exceeded the allowed standards of China (Wan et al., 2008). Jinzhou Bay has been identified as one of the main heavy metal-polluted coastal regions along the Chinese coastline (Wan et al., 2008). In the areas surrounding the submarine outfall of the Gulf of Thermaikos, which is the second largest metropolitan centre in Greece with a population of over 1,000,000 inhabitants, concentrations lower than in Guarujá $(\mathrm{Cu}: 0.003 \mathrm{mg} / \mathrm{L})$ were detected (Christophoridis et al., 2009). Trace metals (e.g., Cu) are highly persistent in the environment and may be toxic even at low concentrations (Wan et al., 2008). Stofberg et al. (2011) quantified the effect of $\mathrm{Cu}$ on the survival of larvae of Haliotismidae (a marine gastropod mollusc) and reported a significant reduction in survival $(\mathrm{LC} 50=5.58 \mu \mathrm{g} / \mathrm{L})$. Thus, the concentrations of Cu detected in the Guarujá water $(38.00$ and $88.00 \mu \mathrm{g} / \mathrm{L})$ could have the potential to interfere with the survival of some aquatic species, at least during the early life stages.

Besides the traditional chemical and microbiological tests, the use of in vitro assays (such as the Ames test) is a useful methodology to assess water quality (Tabrez et al., 2011). This assay is often used as a screening for in vivo testing to detect the mutagenic potential of environmental samples that often constitute complex mixtures (e.g., sewage discharges) (Mortelmans and Zeiger, 2000; Tabrez et al., 2011). The TA98 (displacement of the reading frame) and TA100 (substitution of base pairs) strains, with and without metabolic activation (S9), are complementary and therefore allow the characterisation of different types of mutations (Mortelmans and Zeiger, 2000; Tabrez et al., 2011). However, the composite sample (points P1 + P2) obtained in the mixing zone of the submarine outfall of Guarujá did not present mutagenic activity for the two lines tested (MI were always <2).

\subsection{Sediment}

The pollutant load from WWTP with preliminary treatments, still containing heavy metals, tends to precipitate and settle in the area surrounding the submarine outfalls (Matthai and Birch, 2000). Thus, due to the persistence of the metals in these sediments, this area is the most suitable compartment for environmental monitoring (Matthai and Birch, 2000; Cesar et al., 2007). In this study, the concentrations of $\mathrm{Al}$ detected in the Guarujá sediment (13600 to $17899 \mathrm{mg} / \mathrm{Kg}$ ) was the largest in relation of the other six metals $(\mathrm{Cd}, \mathrm{Pb}, \mathrm{Cu}, \mathrm{Cr}, \mathrm{Ni}$ and $\mathrm{Zn})$. Domestic sewage is an important source of $\mathrm{Al}$ for the marine environment (Gonzalez et al., 1999). However, its higher concentration in the Guarujá sediment can be explained by the fact 
that this metal is naturally abundant in the soils and sediments of the Brazilian coast (Moreira and Boaventura, 2003). Nevertheless, environmental monitoring is still needed for this metal, since it can bioaccumulate in marine species (Türkmen et al., 2006). Al concentrations of 1.23-10.65 $\mu \mathrm{g} / \mathrm{g}$ were detected in the blue crab (Callinectes sapidus) in Skenderun Bay/Turkey, a region heavily impacted by sewage (Türkmen et al., 2006). In the discharge zone of the submarine sewage outfall of Havana city, Cuba, Al concentrations of $8.60-25.00 \mu \mathrm{g} / \mathrm{g}$ were also detected in the sea urchin Echinometra lucunter (Gonzalez et al., 1999).

Benthic macroinvertebrates are considered bioindicators of environmental quality, responding to changes caused by anthropogenic processes in aquatic systems, such as heavy metal contamination (Brown et al., 2000; Surugiu, 2005). At high concentrations in the sediments, metals are potentially toxic to the benthic community in the vicinity of the outfalls (Padovan et al., 2012). However, the conditions observed in the sediment of Guarujá at both sampling points and seasonal campaigns [concentrations of metals $\mathrm{Cd}, \mathrm{Pb}, \mathrm{Cu}, \mathrm{Cr}, \mathrm{Ni}$ and $\mathrm{Zn}<\mathrm{TEL}$ (Threshold Effect Level); GeoI = 0: basal level (CCME, 2001a)] were not able to cause acute toxicity to the test organism Kalliapseudes schubartii (Crustacea: Tanaidacea).

Although no toxicity was detected, it is important to mention that similar concentrations of metals (below TEL) such as $\mathrm{Cd}, \mathrm{Pb}, \mathrm{Zn}$, and $\mathrm{Ni}$ were also detected in the sediment in areas adjacent to the outfalls of Darwin Harbour (Australia) and Mazatlán Bay (Mexico) (Soto-Jiménez et al., 2011; Padovan et al., 2012). However, a high concentration of these four metals was detected in the tissues of the wandering sponge Spheciospongia (typical of Oceania) (Padovan et al., 2012) and iridescent oysters Crassostrea (typical species of the Gulf of California) (Soto-Jiménez et al., 2011). These examples show that the trace metal concentrations detected in the Guarujá sediment may be potential deleterious for the aquatic biota at long term through bioaccumulation phenomena. Furthermore, only tertiary treatments, not existent in Guarujá, such as chemical precipitation, active carbon adsorption, ion exchange, and reverse osmosis are able to remove heavy metals from sewage systems (Blomqvist et al., 1992).

In the benthic community of marine environments, as observed here, polychaetes are generally the group with the highest taxonomic richness. Polychaetes were also reported to be relevant in marine environments where domestic sewage is introduced (Anderlini and Wear, 1992; Santi and Tavares, 2009). The highest densities of these species, both during the high and low season and for both collection sites, in the area of the Guarujá submarine outfall were mainly attributed to the families Lumbrineridae and Goniadidae (both carnivores) (Fauchald and Jumars, 1979). The high density Lumbrineridae in Guarujá can be explained by the fact that this family is tolerant to environmental disturbance and resistant to organic and heavy metal contaminations from domestic sewage discharges (a condition observed in Guarujá) (Tabatabaie et al., 2009). The family Paraonidae (depositivores) (Fauchald and Jumars, 1979) also stood out in the low season (points P1-LC and P2-LC). However, due to the plasticity of polychaete species (containing both sensitive and pollution-tolerant taxa), their presence is not always synonymous with polluted areas (Belan, 2003). The polychaete families inventoried in the Guarujá sediments, such as the Lumbrineridae and Glyceridae (Pearson, 1975; Rosenberg, 1976), Polynoidae (Rygg, 1985), and Spionidae (Hily and Glémarec, 1990), have already been detected in organic matter and metal enriched sediments. However, the presence of these families was also indicative of healthy environments and unpolluted sediments (Rygg, 1985; Hily and Glémarec, 1990; Belan, 2003).

In this study, the Amphipoda order was well represented within the Crustacea class, especially during the high season (points P1-HC and P2-HC), where there was a lower level of pollution. Most species of crustaceans are subsurface inhabitants and therefore sensitive to hypoxic/anoxic conditions resulting from the microbial decomposition of organic matter (Smith and Shackley, 2006). This finding makes our results consistent with the published literature, which states that amphipods, due to their higher sensitivity to sediment polluted by sewers (Dauvin and Ruellet, 2007), tend to decrease in abundance and diversity 
under the influence of high organic debris from a submarine outfall (e.g., point P2-LC) (Anderlini and Wear, 1992). The sensitivity of the Amphipoda order was also observed in studies carried out in outfalls of the Spanish coast (De La Ossa Carretero et al., 2008; 2012). Amphipods showed greater sensitivity (decrease of abundance and diversity) in the areas adjacent to sewage outfalls whose discharges were from WWTPs with lower level of treatment (preliminary and primary). Conversely, this decrease was not observed in the adjacent areas of the submarine outfall whose WWTP had a biological activated sludge treatment (De La Ossa Carretero et al., 2008; 2012). Given that amphipods are more sensitive to pollution than other marine species (De La Ossa Carretero et al., 2008), the good representation of these individuals in the adjacent areas of the Guarujá submarine outfall, could reflect a low-level sediment pollution (Dauvin and Ruellet, 2007). In this way, the good representation of amphipods in association with the other conditions already mentioned (plasticity of the polychaeta species, concentrations of six metals < TEL; GeoI $<0=$ uncontaminated sediment, and absence of toxicity to Kalliapseudes schubartii), suggest that the macrofauna of the region surrounding the Guarujá submarine outfall is not under strong contamination stress. These results are somewhat corroborated by the Shannon-Wiener index found here ( $H^{\prime} ; 2.5-3.5$ bits/ind), which indicates healthy environments and/or unpolluted conditions (Zettler et al., 2007; Al-Farraj et al., 2012).

\section{Conclusion}

This study added new information to databases on water and sediment of the Guarujá municipality. This information had not yet been inventoried in the oceanic mixing zone of the Guaruja submarine outfall. Furthermore, the fact that some variables do not meet the quality standards in the water column demonstrates the importance of expanding the monitoring of the dispersion of this sewer plume, to certify that these contaminants are not reaching the tourist beaches of the municipality and causing health public issues. Regarding the occurrence of oils, greases, detergents, nutrients, and heavy metals, these conditions will not improve without installing a secondary and tertiary treatment level on land. This work also points to a need to revise Conama Resolution No. 430 of 2011 (conditions and standards for effluent release in Brazil), so that more sustainable operational criteria for the emissaries installed along the Brazilian coastal zone can be adopted. The data from this work also contributes towards a reflection of stakeholders (civil society, public authorities, and environmental agencies) on the extent to which marine dispersal and self-purification capacity must be relied upon, and the acceptance of future impacts on the environmental effects of strategy. Although the physicochemical and microbiological data indicate a worsening in some water quality variables (notably during the low season), the benthic community (in the submarine outfall's adjacent areas) was not negatively affected by these conditions. However, it is important to mention that interpretations of the temporal changes of communities associated with a pollution gradient should be cautious in a short-term study (Ferraro et al., 1991). This study covered a relatively short period; therefore, monitoring should continue in order to evidence at larger time scale the possible effects of the discharge of Guarujá sewage on the composition and structure of the benthic community.

\section{Acknowledgments}

The authors wish to thank Gilberto Rivero Chang, Edson Wilmsen Ferreira, and Taiane Pires Farias for their support during the field campaigns. Correia AT was supported by national funds through FCT - Foundation for Science and Technology within the scope of UIDB/04423/2020 and UIDP/04423/2020.

\section{References}

Al-Farraj, S., El- Gendy, A., Al Kahtani, S., \& El- Hedeny, M. (2012). The Impact of Sewage Pollution on Polychaetes of Al Khumrah, South of Jeddah, Saudi Arabia. Research Journal of Chemical and Environmental Sciences, 6: 77-87.

Anderlini, V. C., \& Wear, R. G. (1992). The effect of sewage and natural seasonal disturbances on benthic macrofaunal communities in Fitzroy Bay, Wellington, New Zealand. Marine Pollution Bulletin, 24(1), 21-26. 
APHA - AWWA - WEF. (1999). Standard Methods for the Examination of Water and Wastewater. American Public Health Association, 20th edn. Washington, D. C. ISBN 978-625 0875532-356

APHA - AWWA - WEF. (2005). Standard Methods for the Examination of Water and Wastewater. American Public Health Association, 21st edn. Washington, D. C. ISBN 978- 628 0875530-475

APHA, AWWA - WEF. (2012). Standard Methods for the Examination of Water and Wastewater. American Public Health Association, 22nd edn. Washington, D. C. ISBN 978- 631 087553-0130

APHA, AWWA - WEF. (2017). Standard Methods for the Examination of Water and Wastewater. American Public Health Association, 21st edn. Washington, D. C. ISBN: 978-634 087553-2875.

Baptistelli, S.C., \& Marcellino, E.B. (2016). Seawater Monitoring under the Influence of Sabesp Sea Outfalls in Baixada Santista (South Coast) and North Coast - São Paulo State - Brazil. Revista DAE., 64, 47-56.

Belan, T. A. (2003). Benthos abundance pattern and species composition in conditions of pollution in Amursky Bay (the Peter the Great Bay, the Sea of Japan). Marine Pollution Bulletin, 46(9), 1111-1119.

Bleninger, T., Falkenberg, A., Trevisan, A., Maranhão, M.O., Ishikawa, M., Ribeiro, P. \& Barletta, R. (2016). Combining measurements, models and decision support systems to optimize outfall sitting. Revista DAE., 64, 81-93.

Blomqvist, S., Larsson, U., \& Borg, H. (1992). Heavy metal decrease in the sediments of a Baltic Bay following tertiary sewage treatment. Marine Pollution Bulletin, 24(5), 258-266.

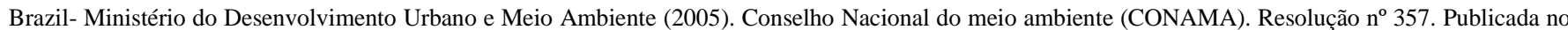
Diário Oficial da União $n^{\circ} 053$, de 18/03/2005.

Brown, S. S., Gaston, G. R., Rakocinski, C. F., \& Heard, R. W. (2000). Effects of Sediment Contaminants and Environmental Gradients on Macrobenthic Community Trophic Structure in Gulf of Mexico Estuaries. Estuaries, 23(3), 411.

CCME - Canadian Council of Ministers of the Environment (2001a). Canadian sediment quality guidelines for the protection of aquatic life: summary tables. Canadian environmental quality guidelines. Winnipeg. https://www.elaw.org/system/files/sediment_summary_table.pdf

CCME - Canadian Council of Ministers of the Environment (2001b). Canadian water quality guidelines for the protection of aquatic life. Canadian environmental quality guidelines. http://ceqgrcqe.ccme.ca/download/en/137

Cesar, A., Choueri, R. B., Riba, I., Morales-Caselles, C., Pereira, C. D. S., Santos, A. R., \& DelValls, T. A. (2007). Comparative sediment quality assessment in different littoral ecosystems from Spain (Gulf of Cadiz) and Brazil (Santos and São Vicente estuarine system). Environment International, 33(4), 429-435.

Cetesb - Companhia Estadual de Tecnologia e Saneamento ambiental (2017). Relatório de qualidade das águas costeiras no estado de São Paulo 2016. Série Relatórios/Agência Ambiental do Estado de São Paulo. ISSN 0103-4103.

Cetesb - Companhia Estadual de Tecnologia e Saneamento ambiental (2011). Guia Nacional de Coleta e Preservação de Amostras - Água, Sedimento, Comunidades Aquáticas e Efluentes Líquidos. Cia. Ambiental do Estado São Paulo. São Paulo. Brazil. 326 pp.

Christophoridis, C., Dedepsidis, D., \& Fytianos, K. (2009). Occurrence and distribution of selected heavy metals in the surface sediments of Thermaikos Gulf, N. Greece. Assessment using pollution indicators. Journal of Hazardous Materials, 168(2-3), 1082-1091.

Colaiuda, V., Federica, Di D., Lombardi, A., Ippoliti, C., Giansante, C., Latini, M., Tomassetti, B. (2021). Evaluating the impact of hydrometeorological conditions on E. coli concentration in farmed mussels and clams: experience in Central Italy. Journal of Water \& Health, 19 (3): $512-533$.

Cromey, C. J., Black, K. D., Edwards, A., \& Jack, I. A. (1998). Modelling the Deposition and Biological Effects of Organic Carbon from Marine Sewage Discharges. Estuarine, Coastal and Shelf Science, 47(3), 295-308.

Dauvin, J. C., and Ruellet, T., 2007. Polychaete/amphipod ratio revisited. Marine Pollution Bulletin, 55, $215-224$.

De la Ossa Carretero, J. A., del Pilar Ruso, Y., Giménez Casalduero, F., \& Sánchez Lizaso, J. L. (2007). Effect of Sewage Discharge in Spisulas ubtruncata (da Costa 1778) Populations. Archives of Environmental Contamination and Toxicology, 54(2), 226-235.

De La Ossa Carretero, J. A., Simboura, N., Del-Pilar-Ruso, Y., Pancucci-Papadopoulou, M. A., Giménez-Casalduero, F., \& Sánchez-Lizaso, J. L. (2012). A methodology for applying Taxonomic Sufficiency and benthic biotic indices in two Mediterranean areas. Ecological Indicators, $23,232-241$.

De Souza Abessa, D.M., De Figueredo Rachid, B.R., De Oliveira Moser, G.A., \& De Oliveira, A.J.F.C. (2012). Environmental effects of sewage oceanic disposal by submarine outfalls: a review. Mundo da Saúde, 36, 643-661.

Elías, R., Palacios, J. R., Rivero, M. S., \& Vallarino, E. A. (2005). Short-term responses to sewage discharge and storms of subtidal sand-bottom macrozoobenthic assemblages off Mar del Plata City, Argentina (SW Atlantic). Journal of Sea Research, 53(4), $231-242$.

Embrapa - Empresa Brasileira de Pesquisa Agropecuária (2011). Centro Nacional de Pesquisas de Solos. Manual de métodos de análises de solos. Embrapa Solos. Rio de Janeiro. Brasil. $2^{\circ}$ ed. 230 pp. ISSN 1517-2627.

Fauchald, K., \& Jumars, P. A. (1979). The diet of worms: a study of polychaete feeding guilds. Oceanography and Marine Biology Annual Review, 17, 193284.

Ferraro, S. P., Swartz, R. C., Cole, F. A., \& Schults, D. W. (1991). Temporal changes in the benthos along a pollution gradient: Discriminating the effect of natural phenomena from sewage-industrial wastewater effects. Estuarine coastal shelf science journal, 33(4), 383-407. 


\section{I}

Gonzalez, H., Pomares, M., Ramirez, M., \& Torres, I. (1999). Heavy metals in organisms and sediments from the discharge zone of the submarine sewage outfall of Havana city, Cuba. Marine Pollution Bulletin, 38, 1048-1051.

Gray, J.S., Wu, R.S., \& Or, Y.Y. (2002). Effects of hypoxia and organic enrichment on the coastal marine environment. Marine Ecology Progress, 238, 249279.

Grevskott, D. H., Salvà-Serra, F., Moore, E. R. B., \& Marathe, N. P. (2020). Nanopore sequencing reveals genomic map of CTX-M-type extended-spectrum $\beta$ lactamases carried by Escherichia coli strains isolated from blue mussels (Mytilus edulis) in Norway. BMC Microbiology, 20(1).

Hammer, Ø., Harper, D. A. T., \& Ryan, P. D. (2001). PAST: Paleontological Statistics Software Package for Education and Data Analysis. Palaeontol. Electronica. 4(1), 9 pp.

Heisler, J., Glibert, P.M., Burkholder, J.M., Anderson, D.M., Cochlan, W., Dennison, W.C., Dortch, Q., Gobler, C.J., Heil, C.A., Humphries, E., Lewitus, A., Magnien, R., Marshall, H.G., Sellner, K., Stockwell, D.A., Stoecker, D.K., \& Suddleson, M. (2008). Eutrophication and harmful algal blooms: A scientific consensus. Harmful Algae, 8(1), 3-13.

Hily, C., \& Glémarec, M. (1990). Dynamique successionnelle des peuplements de fonds meubles an large de la Bretagne. Oceanologica Acta, 13, 107-115.

Hollander M., \& Wolfe D.A. (2013). Nonparametric statistical methods. John Wiley \& Sons. New York. USA. $3^{\circ}$ ed. 848 pp. ISBN: 978-0-470-38737-5

Howarth, R.W. (2008). Coastal nitrogen pollution: A review of sources and trends globally and regionally. Harmful Algae, 8, 14-20.

Ibge - Instituto brasileiro de Geografia e Estatística (2018). Estimativa da população brasileira. Rio de Janeiro. Brasil.

Lamparelli, C.C., \& Ortiz, J.P. (2007). Emissários submarinos: projeto, avaliação de impacto ambiental e monitoramento. São Paulo: Cetesb. Brazil. 1. 12-23. ISBN: 978-85 86624-49-0

León, V. M., López, C., Lara-Martín, P. A., Prats, D., Varó, P. \& González-Mazo, E. (2006). Removal of linear alkylbenzene sulfonates and their degradation intermediates at low temperatures during activated sludge treatment. Chemosphere, 64(7), 1157-1166

Libhaber, M. (2016). Economic, Regulatory and Social Aspects Related to Wastewater Ocean Disposal through Submarine Outfalls. Revista DAE., 64, 5-20.

Luckenbach, M. W., Huggett, D. V., Zobrist, E. C. (1988). Sediment Transport, Biotic Modifications and Selection of Grain Size in a Surface Deposit-Feeder. Estuaries, 11(2), 134 .

Magurran, A.E. (1988). Ecological diversity and its measurement. Princeton University Press. Princeton, New Jersey, USA. 179 pp. ISBN: 9780691084916

Matthai, C., \& Birch, G.F. (2000). Trace metals and organochlorines in sediments near a major ocean outfall on a high energy continental margin (Sydney, Australia). Environment Pollutution, 110, 411-23.

Mingoti, S. A. (2005). Análise de dados através de métodos de estatística multivariada: uma abordagem aplicada. Ed. UFMG. Belo Horizonte. Brazil. 295 pp. ISBN: 85-7041-451-X.

Moreira, R.C.A., \& Boaventura G.R. (2003). Referência geoquímica regional para a interpretação das concentrações de elementos químicos nos sedimentos da bacia do Lago Paranoá - DF. Química Nova, 26(6), 812-820. ISSN 0100-4042.

Mortelmans, K., \& Zeiger, E. (2000). The Ames Salmonella/microsome mutagenicity assay. Mutation Research/Fundamental and Molecular Mechanisms of Mutagenesis, 455(1-2), 29-60.

Moser, G. A. O., Sigaud-Kutner, T. C. S., Cattena, C. O., Gianesella, S. M. F., Braga, E. S., Schinke, K. P., \& Aidar, E. (2004). Algal growth potential as an indicator of eutrophication degree in coastal areas under sewage disposal influence. Aquatic Ecosystem Health \& Management, 7(1), 115-126.

Nunes, B., Miranda, M.T., \& Correia, A.T. (2016). Absence of effects of different types of detergents on the cholinesterasic activity and histological markers of mosquitofish (Gambusia holbrooki) after a sub-lethal chronic exposure. Environment Science Pollution Research, 23, 14937-14944.

OECD - Organisation for Economic Co-operation and Development (1987). Guideline for Testing of Chemicals/Section 4. "Bacterial Reverse Mutation Test". Method 471. Adopted: 21st July 1997.

Ole Kusk, K. O., \& Petersen, S. (1997). Acute and chronic toxicity of tributyltin and linear alkylbenzene sulfonate to the marine copepod Acartiatonsa. Environmental Toxicology and Chemistry, 16(8), 1629-1633.

Olalemi, A., Baker-Austin, C., Ebdon, J., \& Taylor, H. (2016). Bioaccumulation and persistence of faecal bacterial and viral indicators in Mytilus edulis and Crassostrea gigas. International Journal of Hygiene and Environmental Health, 219(7), 592-598.

Oliveira, A. M. S., Baraúna, R. A., Marcon, D. J., Lago, L. A. B., Silva, A., Lusio, J., \& Schneider, M. P. C. (2020). Occurrence, antibiotic-resistance and virulence of $E$. coli strains isolated from mangrove oysters (Crassostrea gasar) farmed in estuaries of Amazonia. Marine Pollution Bulletin, $157,111302$.

Ortiz, J.P., Braulio, A., \& Yanes, J.P. (2016). Wastewater Marine Disposal through Outfalls on the coast of São Paulo State Brazil: An overview. Revista DAE., 64, 29-46.

Padovan, A., Munksgaard, N., Alvarez, B., McGuinness, K., Parry, D., \& Gibb, K. (2012). Trace metal concentrations in the tropical sponge Spheciospongia vagabundaat a sewage outfall: synchrotron X-ray imaging reveals the micron-scale distribution of accumulated metals. Hydrobiologia, 687(1), 275-288.

Pelling, M., \& Blackburn, S. (2013). Megacities and the Coast, Megacities and the Coast: Risk, Resilience and Transformation. Routledge. London. UK., 1, 272. 
Pearson, T.H. (1975). The benthic ecology of Loch Linne and Loch Eli, a sea-Loch system on the west coast of Scotland. IV. Changes in the benthic fauna attributable to organic enrichment. Journal of Experimental Marine Biology and Ecology, 20: 1-41.

Ribeiro, A.L.P.M., \& Oliveira, R.C (Orgs). (2015). Baixada Santista: uma contribuição à análise geoambiental. UNESP. São Paulo. Brazil. 1ª ed. pp. 255. ISBN 978-85-68334-55-3

Rygg, B., 1985. Distribution of species along pollution induced diversity gradients in benthic communities in Norwegian fjords. Marine Pollution Bulletin, 16, 469-474.

Roberts, P.J.W. (2016). Treatment Options for Marine Wastewater Discharges. Revista DAE., 64, 21-28.

Rosenberg, R. (1976). Benthic Faunal Dynamics during Succession Following Pollution Abatement in a Swedish Estuary. Oikos, 27(3), 414.

Roslev, P., Iversen, L., Sønderbo, H. L., Iversen, N., \& Bastholm, S. (2009). Uptake and persistence of human associated Enterococcus in the mussel Mytilus edulis: relevance for faecal pollution source tracking. Journal of Applied Microbiology, 107(3), 944-953.

Roveri, V., Guimarães, L. L., \& Correia, A. T. (2020a). Spatial and temporal evaluation of the urban runoff water flowing into recreational areas of Guarujá, São Paulo State, Brazil. International Journal of River Basin Management, 1-0.

Roveri, V., Guimarães, L. L., \& Correia, A. T. (2020b). Temporal and spatial variation of benthic macroinvertebrates on the shoreline of Guarujá, São Paulo, Brazil, under the influence of urban surface runoff. Regional Studies in Marine Science, 36, 101289.

Roveri, V., Guimarães, L. L., Correia, A. T., Demoliner, M., \& Spilki, F. R. (2020c). Occurrence of human adenoviruses in a beach area of Guarujá, São Paulo, Brazil. Water Environment Research.

Roveri, V., Guimarães, L. L., \& Correia, A. T. (2021). Mutagenic and ecotoxicological assessment of urban surface runoff flowing to the beaches of Guarujá, State of São Paulo, Brazil. Water Science \& Technology, 83 (12): 3054-3062.

Rozen, Y., \& Belkin, S. (2001). Survival of enteric bacteria in seawater. FEMS Microbiology Reviews, 25(5), 513-529.

Santi, L., \& Tavares, M. (2009). Polychaete assemblage of an impacted estuary, Guanabara Bay, Rio de Janeiro, Brazil. Brazilian Journal of Oceanography, 57(4), 287-303.

Selegean, J.P.W., Kusserow, R., Patel, R., Heidtke, T. M., \& Ram, J. L. (2001). Using zebra mussels to monitor Escherichia coli in environmental waters. Journal of Environmental Quality, 30, 171-179.

Smith, J., \& Shackley, S. E. (2006). Effects of the closure of a major sewage outfall on sublittoral, soft sediment benthic communities. Marine Pollution Bulletin, 52(6), 645-658.

Soto-Jiménez, M., Páez-Osuna, F., \& Morales-Hernández, F. (2001). Selected trace metals in oysters (Crassostrea iridescens) and sediments from the discharge zone of the submarine sewage outfall in Mazatlán Bay (southeast Gulf of California): chemical fractions and bioaccumulation factors. Environment Pollution, 114 (3), 357370.

Stalmans, M., Matthijs, E., \& De Oude, N. T. (1991). Fate and Effect of Detergent Chemicals in the Marine and Estuarine Environment. Water Science and Technology, 24(10), 115-126.

Stofberg, R.L., Simon, C.A., \& Snynman, R.G. (2011). Effects of heavy metals on the development and survival of abalone Haliotismidae larvae. African Journal of Marine Science, 33(2), 339-345.

Stoll, J.A., Poiger, T. F., Sturm, M., Giger, W. (1997). Fluorescent Whitening Agents as Molecular Markers for Domestic Wastewater in Recent Sediments of Greifensee, Switzerland. Molecular Markers in Environmental Geochemistry, 671, 231-241.

Surugiu, V., 2005. The use of polychaetes as indicators of eutrophication and organic enrichment of coastal waters: a study case-Romanian Black Sea Coast. AnaleleŞtiinţifice ale Universităţii “Al.I. Cuza” Iaşi, s. Biologie animal, 51, 55-62.

Tabatabaie, T., Amiri, F., Nabavi, M. B., Fazeli, M.S., \& Afkhami, M. (2009). Study on the effect of sewage pollutant of bandar imam petrochemical company on benthic macrofauna community mossa creek using biodiversity indices and bioindicators. Asian Journal of Biotechnology, 1, 20-28.

Tabrez, S., Shakil, S., Urooj, M., Damanhouri, G. A., Abuzenadah, A. M., \& Ahmad, M. (2011). Genotoxicity testing and biomarker studies on surface waters: An overview of the techniques and their efficacies. Journal of Environmental Science and Health Part C Environmental Carcinogenesis \& Ecotoxicology, 29, $250-275$.

Türkmen, A., Türkmen, M., Tepe, Y., Mazlum, Y., \& Oymael, S. (2006). Metal Concentrations in Blue Crab (Callinectes sapidus) and Mullet (Mugil cephalus) in Iskenderun Bay, Northern East Mediterranean, Turkey. Bulletin of Environmental Contamination and Toxicology, 77(2), $186-193$.

Wan, L., Wang, N., Li, Q., Sun, B., Zhou, Z., Xue, K., \& Song, L. (2008). Distribution of Dissolved Metals in Seawater of Jinzhou Bay, China. Environmental Toxicology and Chemistry, 27(1), 43-48.

Zamboni, A. J., \& Costa, J.B. (2002). Testes de toxicidade com sedimentos marinhos utilizando tanaidáceos. In: Nascimento, I.A.; Sousa, E.C.P.M.; Nipper, M. (eds.) Métodos em Ecotoxicologia Marinha: Aplicações no Brasil. Editora Artes Gráficas e Indústria Ltda, São Paulo, 262pp.

Zettler, M. L., Schiedek, D., \& Bobertz, B. (2007). Benthic biodiversity indices versus salinity gradient in the southern Baltic Sea. Marine Pollution Bulletin, $55(1-6), 258-270$. 